\title{
A Participationist Approach to Philosophical Anarchism
}

\author{
by
}

\author{
Phil Bériault
}

A thesis submitted to the Faculty of Graduate and Postdoctoral Affairs in partial fulfillment of the requirements for the degree of

\author{
Master of Arts
}

in

Philosophy

Carleton University

Ottawa, Ontario

(C) 2014, Phil Bériault 


\section{Abstract}

Within political philosophy, philosophical anarchists have argued that states and their authority are illegitimate. What this means is that political obligation is not morally sound, and that states do not possess a moral right to authority. Various approaches to philosophical anarchism have been developed, all claiming to effectively demonstrate the illegitimacy of states. However, upon closer analysis, some of the most influential philosophical anarchist arguments seem to be lacking in crucial respects, and as such, fail to demonstrate the illegitimacy of states. These shortcomings, however, do not entail that philosophical anarchism itself is necessarily false, only that current approaches fail to fully appreciate all of the relevant considerations when evaluating state legitimacy. Participationism offers the philosophical anarchist with a means to effectively argue for the illegitimacy of states, while sharing none of the shortcomings of other approaches. Developing and analyzing such an approach will be the goal of this thesis. 


\section{Acknowledgments}

I would like to acknowledge the entire Department of Philosophy at Carleton University for having been an invaluable source of comradery and inspiration. I am where I am now because of the incredible people who make up the Department of Philosophy and the philosophical community surrounding it. From my fellow students, to the department administrator, Sandra Kirkpatrick, and to the teaching faculty; each are owed my sincere gratitude for having me as part of their community. Without them, I very much doubt that I would have had the ability and confidence to actually construct and present this thesis. For this, I offer my humble acknowledgement of their contribution in my development as a student and as a philosopher.

I would also like to give a special acknowledgement to my thesis supervisor, Dr. Jay Drydyk, whose openness to my project and incredible patience with me in developing it ensured that this thesis has actually seen the light of the day. It is difficult to imagine that this thesis would be here now had it not been for his guidance and ability to tolerate my style of work. His comments and challenges have aided me greatly in writing this thesis, and for this, I am truly grateful. 


\section{Table of Contents}

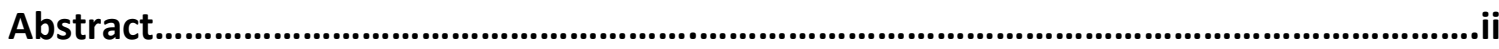

Acknowledgements.................................................................................................................iii

Table of Contents......................................................................................................................iv

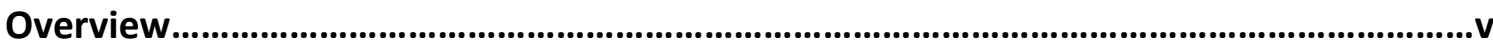

1 Literature Review: Philosophical Anarchism and Participationism.............................1

$1.1 \quad$ Introduction to Philosophical Anarchism.......................................................1

1.2 Preliminary Comments..............................................................................2

1.3 Two Approaches to Philosophical Anarchism.............................................6

1.4 Robert Paul Wolff and A Priori Anarchism...............................................7

1.5 A. John Simmons and A Posteriori Anarchism........................................14

1.6 Weak and Strong Philosophical Anarchism.............................................27

1.7 Summation of Philosophical Anarchism.....................................................30

1.8 Introduction to Participationism..................................................................31

1.9 The Moral Dimension of Participationism.................................................33

1.10 Preliminary Comments on Autonomy........................................................34

1.11 The Practice of Autonomy..........................................................................35

1.12 The Defense of Autonomy..................................................................38

1.13 The Development of Autonomy...............................................................41

1.14 Autonomy, Properly Understood.................................................................45

1.15 The Practical Dimension of Participationism..............................................46

1.16 Participatory Budgeting in Kerala, India...................................................47

1.17 Participatory Community Planning in Chicago, U.S.A................................52

1.18 Participatory Workplace Management in Argentina.................................56

1.19 Summation on Participationism................................................................59

2 Article: A Participationist Approach to Philosophical Anarchism ................................60

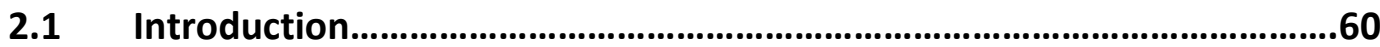

2.2 Understanding the Concepts.......................................................................61

2.3 A Priori and A Posteriori Anarchism........................................................66

2.4 Evaluating Philosophical Anarchism......................................................70

2.5 The Move to Participationism.................................................................76

2.6 Evaluating Participationism.....................................................................81

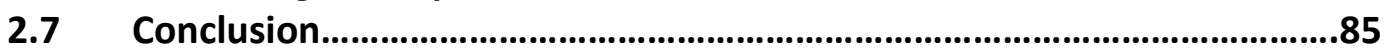

Bibliography.................................................................................................................... 


\section{Overview}

The purpose of my thesis is to develop a participationist approach to philosophical anarchism. To do this, I have chosen to do a literature review followed by an article that outlines my own arguments in relation to the topics covered in the literature review. My literature review will cover the two major topics relevant to developing a participatory approach to philosophical anarchism. The first topic that I will cover will be philosophical anarchism, wherein I analyze its approach to the moral illegitimacy of states. To do so, I will cover both what common characteristics an argument must have to be understood as philosophically anarchist, as well as the two major approaches to this argument. The next section will be on participationist democratic theory, analyzing both its theoretical and practical forms. The purpose of this section will be to come to clear understanding of the type of commitments made by participationist democratic theory and how these commitments are reflected in practice. Finally, I present my own article where I present a participatory approach to philosophical anarchism. In it, I argue that a participationist approach to political obligation overcomes some of the shortcomings that can be attributed to philosophical anarchism yet is still ultimately a philosophical anarchist argument.

My literature review will begin by covering philosophical anarchism. After introducing its significance, I begin with an analysis of what makes an argument philosophically anarchist by discussing the characteristics of philosophical anarchism outlined by A. John Simmons in his essay "Philosophical Anarchism" (Simmons 2001). The characteristics that I will cover will be the conclusion that political obligation is 
morally unsound, and that citizens are thus not morally bound to their state, but that other moral obligations are still owed. I then turn to an analysis of two distinct approaches to philosophical anarchism; the arguments outlined by Robert Paul Wolff's book In Defense of Anarchism (Wolff 1970) and by Simmons in his essay "Legitimacy and Justification" (Simmons 2001). The purpose here will be to come to an understanding of the $a$ priori and a posteriori approaches to philosophical anarchism, which see political obligation as either necessarily or contingently morally illegitimate. After this analysis, I also make note of the distinction between weak and strong philosophical anarchism, where the possible strength of one's obligation to oppose political obligation is analyzed, as outlined by Simmons's "Philosophical Anarchism" (Simmons 2001). This analysis of philosophical anarchism will lead to a precise understanding of how philosophical anarchism understands the moral nature of a citizen's obligations within a political community.

Afterwards, I cover literature related to participationist approaches to democracy to understand both its normative commitments and how those commitments have motivated some real world democratic decision-making models. To understand the theoretical dimension of participationism, I analyze the theory advanced by Carole Pateman in Participation and Democratic Theory (Pateman 1970). Particularly, I identify the practice, defense, and development of autonomy as the major values motivating participationism, and I show how these values lead to particular normative commitments with regard to democratic governance. Afterwards, I analyze examples of participationism in practice in municipal budgeting, community 
governance, and workplace management. First, I look at an analysis by T. M. Thomas Isaac and Patrick Heller of the participatory budgeting of development aid in the Indian state of Kerala from their essay "Democracy and Development: Decentralized Planning in Kerala" (Isaac and Heller 2003). Next, I look at the participatory governance of Chicago's public schools and beat officers as discussed by Archon Fung's “Deliberative Democracy, Chicago Style: Grass-roots Governance in Policing and Public Education" (Fung 2003). Lastly, I will discuss Marie Trigona's overview of the participatory management at place in a textile factory in Argentina from her article "Fasinpat (Factory Without A Boss): An Argentine Experience in Self-Management" (Trigona 2008). I conclude that participationist approaches to democratic theory advance a particular understanding and value of autonomy that results in particular democratic mechanisms.

Finally, I complete my thesis with an article in which I develop a participationist approach to philosophical anarchism drawing on the topics covered in my literature review. I begin by advancing a particular understanding of political obligation developed from my analysis of Pateman's participationist and Wolff and Simmons's philosophical anarchist approaches to political obligation, arguing that political obligation must be the result of one's own undertaking and acceptance of that obligation. I then argue that this understanding of political obligation rules out the possibility of Wolff's a priori anarchism, and that if any philosophical anarchist argument is to hope for plausibility it must approach political obligation as a posteriori morally sound, as outlined by Simmons. I then discuss some of the shortcomings with Simmons's arguments, specifically with regards to what I argue is a contradiction between Simmons's own 
arguments against certain conceptions of political obligation and his own conception. I then argue that a participationist approach to political obligation overcomes the shortcomings of Simmons's argument. Afterwards, I present Pateman's argument that participationism is not philosophically anarchist, arguing that when political obligation is understood as a posteriori morally legitimate, participationism can be developed in way that commits itself to philosophical anarchism. I conclude that a participatory approach to philosophical anarchism is not only valid but also the most plausible given the commitments made by both participationists and philosophical anarchists. 


\section{Literature Review: Philosophical Anarchism and Participationism}

\subsection{Introduction to Philosophical Anarchism}

A significant issue within political philosophy has been the nature of political obligation, that is, the nature of one's "moral duty to obey the laws of one's country or state" (Dagger 2010). Although there are many questions surrounding political obligation, there is one particular question that must be answered in order for any account of political obligation to hope for validity. The question: How is political obligation morally sound? Arguments addressing which sorts of states can claim political obligation from its citizens, the extent of that political obligation, and just what obligations are included in political obligation all must, in some sense, advance a particular position with regards to the moral legitimacy of political obligation. The significance of addressing how political obligation can be morally legitimate should be clear; without such an explanation, no coherent and comprehensive argument regarding the normative aspects of political philosophy can be made. So central is the question of the moral legitimacy of political obligation to political philosophy that Robert Paul Wolff refers to it as the founding principle of all political philosophy (Wolff 1970, 3).

One position within political philosophy that has primarily been concerned with the notion of the moral plausibility of political obligation is, specifically, a skeptical position which presents challenges to arguments which claim that in some sense political obligation is morally sound. This position within political philosophy has been referred to as philosophical anarchism, and it will be where I start my literature review. 
In understanding the philosophical anarchist position, I begin with a general analysis of philosophical anarchism, addressing what different approaches to philosophical anarchism have in common, what they entail, and what they do not entail. I then begin a more specific analysis of two influential approaches to philosophical anarchism to understand the precise forms that philosophical anarchist arguments take. The first is Robert Paul Wolff's a priori anarchism, and the second approach is A. John Simmons's a posteriori anarchism. I then address an important distinction between weak and strong anarchism, which have different normative commitments. Finally, I close this section with a brief overview of how we can understand philosophical anarchism more generally as well as its possibilities given the preceding review.

\subsection{Preliminary Comments on Philosophical Anarchism}

Before analyzing specific philosophical anarchist arguments, it would help to first understand why these arguments are referred to as arguments that advance philosophical anarchism. To do so, I analyze three general characteristics outlined by A. John Simmons that all philosophical anarchist arguments share: the common conclusion that arguments and forms of political obligation are morally unsound, that this conclusion entails a certain understanding of our relationship to the state, and a common understanding of what a philosophical anarchist argument does not entail. These three characteristics are significant for understanding the general philosophical anarchist argument against political obligation by expressing a common conclusion and conception of the nature of the relationship between the citizen and the state. For this 
reason, I believe that such an understanding is necessary before analyzing specific philosophical anarchist arguments so as to understand the potential importance of them to political philosophy.

The first, and most definitive, characteristic common amongst all philosophical anarchist arguments is the conclusion that all existing states, and by extension, political obligation to them, are morally unsound (Simmons 2001, 103-104). No matter if an argument is premised on liberty, or mutual aid, or egalitarianism, if the argument concludes that existing states are illegitimate in lieu of that premise, then the argument can be understood as philosophically anarchist. Additionally, since political obligation is understood as following only from state legitimacy, the absence of existing legitimate states results in the absence of morally legitimate political obligation to those states (Simmons 2001, 106). As such, all philosophical anarchist arguments also share the conclusion that political obligation to any state is morally unsound. Regardless of how the argument is made, and regardless of the values that motivate the argument, all philosophical anarchist arguments share this conclusion: that no morally sound political obligation exists.

This common conclusion leads to a particular understanding of the citizen-state relationship that is also shared by all philosophical anarchists. Namely, no one is morally bound to the state, and is therefore free to adopt what Simmons refers to as the "balance-of-reasons" approach with regards to political obligation (Simmons 2001, 108). Since political obligation is morally unsound, our obligations to the state to obey law and policy cannot be morally absolute when determining how one ought to act; 
political obligations can possibly be over-ridden by more important moral reasons.

Thus, the law and policy of one's state is understood as morally non-binding, and whatever obligation is owed to the state is to be thought of as just one reason among many when deliberating on how to act. As Simmons puts it, "the practical stance with the respect to the state, the philosophical anarchist maintains, is one of careful consideration and thoughtful weighing of all of the reasons that bear on action in a particular set of political circumstances" (Simmons 2001, 109). This leads philosophical anarchists to conclude that the relationship between the citizen and the state is not one where obedience is morally owed to the state, but rather is something worthy of consideration when engaged in political deliberation.

The understanding of the citizen-state relationship developed by philosophical anarchism also leads to an understanding of what their arguments do not entail. Most significantly, although there is no morally legitimate political obligation, that does not mean one is given absolute license to do whatever they please (Simmons 2001, 110). Simply put, the absence of moral obligation does not follow from the absence of political obligation. Although there is no morally sound political obligation, there may be (and usually are) still strong moral reasons not to engage in certain types of actions. Further, what may be a sound moral obligation (and perhaps many more) may also happen to be an obligation demanded by one's state. As such, a philosophical anarchist argument does not necessarily entail that one is morally permitted to engage in acts that the state regards as breaking the law; the we still have "general duties to our fellow 
citizens qua persons" (Simmons 2001, 110). ${ }^{1}$ This idea helps to understand what the nature of the citizen-citizen relationship is to the philosophical anarchist, namely that moral obligations are still owed to others regardless of an absence of political obligation. For this reason, it is important to note this characteristic of philosophical anarchism.

These characteristics of philosophical anarchism are important to understand because they outline a basic understanding of the moral relationship a citizen has in a political community. For philosophical anarchism, citizens are not politically obligated to their state and thus there is no presumption of moral supremacy made in favour of the laws and policy of the state. This makes the citizen morally permitted to treat their obligation demanded by the state as non-binding and to consider for themselves how to act in political communities. Lastly, the philosophical anarchist recognizes the force of moral reasons to still uphold obligations and duties that are owed to others although there exists no morally legitimate political obligation. This understanding of the citizen's place within a political community and their moral obligations in relation to it is necessary to understand what makes philosophical anarchism unique in its approach to political obligation. With this understanding, I now turn to specific philosophical anarchist arguments.

\footnotetext{
${ }^{1}$ It may not be the case, however, that all of the activities prohibited by the state are actually morally impermissible, and it is possible that perhaps there may actually be an obligation to oppose the state in certain political circumstances. This possibility will be discussed in 1.6.
} 


\subsection{Two Approaches to Philosophical Anarchism}

There are two unique forms that a philosophical anarchist argument can take, each with their own way of understanding the conditions for morally sound political obligation, and as a result, their own arguments regarding the moral implausibility of political obligation. These two approaches are commonly referred to as a priori anarchism and a posteriori anarchism (Simmons 2001, 104-105). A priori anarchism understands political obligation in such a way that any and all appeals to political obligation are morally unsound. To a priori anarchism, the very nature of political obligation is such that any instance of it will be morally unsound (Simmons 2001, 105). On the other hand, a posteriori anarchism understands the moral implausibility of political obligation as the result of existing forms of political obligation failing to uphold some weightier moral obligation, or as not possessing certain necessary virtues (Simmons 2001, 105). The significance between these two argumentative approaches to philosophical anarchism with regards to their philosophical commitments should be clear. For the a priori anarchist, morally legitimate political obligation is a conceptual impossibility whereas the a posteriori anarchist argues that existing forms of political obligation fail to achieve moral soundness.

To fully understand these two approaches to philosophical anarchism, I will be looking at two influential arguments that each pursue one of these approaches in contemporary political philosophy. First, I analyze Wolff's philosophical anarchist argument made in In Defense of Anarchism (Wolff 1998), which not only provides an example of an a priori anarchist argument but is also one of the most influential and 
significant works in contemporary philosophical anarchism. I then turn to Simmons's philosophical anarchist argument made in his influential essay "Justification and Legitimacy" (Simmons 2001), which will allow me to develop an understanding of $a$ posteriori anarchism. Understanding these two philosophical anarchist arguments will illuminate the differences between the a priori and a posteriori approaches to philosophical anarchism and to understand the unique philosophical commitments that each argument makes.

\subsection{Robert Paul Wolff and A Priori Anarchism}

The first philosophical anarchist argument that I will analyze will be one made by Robert Paul Wolff in his influential book In Defense of Anarchism (1998). I begin this analysis by first presenting Wolff's approach to understanding both political obligation as well the moral implications of autonomy, so as to understand his conceptual foundations. I then outline his argument that the theoretical and practical conflicts between political obligation and autonomy result in the moral illegitimacy of political obligation, as political obligation contradicts the necessity of autonomous decisionmaking for moral obligation. Afterwards, I show how Wolff's argument reflects each of the characteristics of philosophical anarchism outlined in Part 1, demonstrating that Wolff's argument falls within the category of philosophical anarchism. Finally, I discuss how Wolff's philosophical anarchism is best classified as an a priori anarchist approach to the moral illegitimacy of political obligation. 
In order to understand Wolff's approach to understanding political obligation, it will be necessary to analyze his understanding of authority and the state. For Wolff, authority is "the right to command, and correlatively, the right to be obeyed" and the state is "a group of persons who have and exercise supreme authority within a given territory" (Wolff 1998, 3-4). What this means is that in political communities and matters, the state is the sole authority, and that as such is owed our political obligation. This leads Wolff to conclude that the "defining mark of the state is authority, the right to rule" (Wolff 1998, 18). This understanding of the state that is owed political obligation should be contrasted, however, with what Wolff calls de facto states; that is, states that happen to possess and exercise supreme power (Wolff 1998, 5, 19). In order to determine the moral legitimacy of a state's authority, and by extension political obligation, an account of how the state has the right to command and be obeyed must be given, and not simply an empirical account of a state's power (Wolff 1998, 8). As such, we can understand Wolff's approach to political obligation as one where the moral duty to obey the laws and policies of one's state is the result of a state that possesses the right, and not just the power, to exercise authority.

Wolff then turns his attention to developing an understanding of autonomy and its moral implications. Wolff defines autonomy as the capacity for self-legislation that is the product of one's capacity to choose how to act as well as their ability to rationally reason and deliberate about how they ought to act (Wolff 1998, 12, 14). Wolff argues that the capacity for autonomy means that at the end of the day anybody possessing autonomy has an obligation to take responsibility for their actions (Wolff 1998, 13). The 
idea that our autonomy makes us morally responsible for our actions, Wolff argues, is at the heart of moral philosophy (Wolff 1998, 12). For Wolff, this is absolutely key in understanding how obligation can be grounded; as he puts it, "Only because [one] has the capacity to reason about [their] choices can [they] be said to stand under a continuing obligation to take responsibility for them" (Wolff 1998, 12). Because of my capacity for autonomous decision-making and the capacity to act autonomously, I am obligated to take responsibility for my actions since I could have acted differently. Thus, Wolff understands the capacity for autonomous decision-making, and the resulting moral responsibility, as the foundation for reasoning about how one ought to act.

With an understanding of how Wolff conceptualizes political obligation and autonomy, we can begin to unpack his argument. Wolff first argues that, theoretically, the authority of that state is in direct conflict with my obligation to be responsible for my actions. Since the state must have authority over me for political obligation to exist, that means it must circumvent my own autonomous decision-making (Wolff 1998, 18). In other words, the authority of my own autonomy and responsibility must be compromised in order to allow the state to have true and meaningful authority and to be able to be the sole imposer of laws and duties. However, as Wolff argues, I have an obligation to be responsible for my actions since I possess the capacity for autonomous decision-making, and as such, have an obligation to defend my authority as the sole imposer of duties for myself (Wolff 1998, 18). My moral obligation to be my own authority comes in direct conflict with the state's claim that it be the sole authority over me, and is thus not, morally permissible (Wolff 1998, 18). Therefore, since the state, 
and the authority it requires, by nature contradict my moral obligations to be responsible for myself, the state, and by extension political obligation to it, cannot be morally legitimate. This theoretical contradiction leads Wolff to conclude that a concept of a de jure state, a state which has the right to enact morally-binding laws and policies and as such is legitimately owed political obligation, is a vacuous concept (Wolff 1998, 19).

Wolff argues for the plausibility of his argument by also analyzing various democratic models of decision-making, showing how they ultimately fail to resolve the conflict between political obligation and one's moral obligation to be autonomous and responsible. Wolff chooses democratic theory as the focus of his analysis as democratic theory explicitly accepts the moral force of autonomy, but seeks to construct a political community that can be legitimately owed political obligation (Wolff 1998, 21-22). ${ }^{2}$ Wolff begins by discussing the possibility of unanimous direct democracy, wherein each and every citizen must each vote and agree on every issue, as a possible solution to the conflict between political obligation and autonomy (Wolff 1998, 23). However, as Wolff argues, the stability of political obligation owed to such a political community can be jeopardized by a single dissenting vote, resulting in the immediate collapse of political obligation that does not require the compromise of personal autonomy (Wolff 1998, 24, 26). Further, as a political community grows, the practical ability to maintain a political

\footnotetext{
2 The reason Wolff only discusses the attempts of democratic theory to resolve this conflict is because of his view that "There is only one form of political community which offers any hope of resolving the conflict between authority and autonomy, and that is democracy" (Wolff 1998, 21). Little is offered in way of argument for why this may be the case other than his observation that "today the belief in all forms of traditional autonomy is as weak as the arguments that can be given for it" (Wolff 1998, 21).
} 
community that can conduct meetings to accommodate every citizen poses a very reasonable concern (Wolff 1998, 26). For Wolff, the restriction of decision-making to unanimity is so strict, both in its vulnerability to moral illegitimation and in its ability to sustain large numbers, that it renders it untenable for the governance of a political community (Wolff, 22-23, 26).

Next, Wolff analyzes representative democracy as a possible resolution to the conflict between political obligation and autonomy. Representative democracy, Wolff notes, is traditionally presented as a means of preserving, in some sense, the value of unanimous direct democracy by resolving the problem of sustaining democratic governance of a large political community (Wolff 1998, 28). However, Wolff identifies three major problems with representative democracy that keep it from legitimately being owed political obligation. The first is that the representative is not obligated to vote on issues the same way as the person who has selected them as their representative would and has no way of effectively determining how each of their constituents feel about a given issue (Wolff 1998, 29). The second is that representatives may be privy to additional information that is necessary to meaningfully deliberate on a given issue that is not available to their constituency or that they simply do not understand, such as in the case of military operations (Wolff 1998, 31). Lastly, the sheer number of possible platforms, each a varied combination of various views on many issues will practically outnumber the number of possible representatives, leaving many citizens unable to select a representative that actually represents what their autonomous decision-making would conclude on a given issue (Wolff 1998, 33). These 
three problems with representative democracy alienate citizens from the actual decision-making process within their political community. As a result, the condition for political obligation within representative democratic political communities is not reflective of the autonomous decision-making of its citizens, and as such is not morally owed political obligation.

Finally, Wolff analyzes the potential of majoritarian democracy to provide a resolution to the problem of morally legitimate political obligation. Majoritarian democratic decision-making is presented as a possible solution to the vulnerability of unanimous direct democracy while still affirming its commitment to the autonomy of citizens (Wolff 1998, 38). However, Wolff identifies various problems with the justification of majoritarian democracy and its ability to preserve the autonomy of citizens, especially with regards to those who may fall into the minority. The first problem lies in the attempt to justify majority rule by way of initially agreed upon terms in a contract that founds the political community (Wolff 1998, 41). Wolff argues that this justification fails as it seeks to morally legitimate political obligation through the submission of autonomy, as the consenters to the contract obligate themselves to the majority (Wolff 1998, 42). This simply presents again the initial conflict between political obligation and the moral obligation to be responsible and autonomous that led to the conclusion that political obligation is morally illegitimate in the first place. Additionally, if all that is required for the moral legitimation of political obligation is initial consent, then any possible decision-making model can potentially be morally legitimate (Wolff 1998, 42). The next problem with majority rule is its attempt to 
legitimate political obligation from those in the minority by arguing that the majority possess greater moral force (Wolff 1998, 44). To do so, Wolff analyzes the arguments made by Rousseau and his conception of the general will as Wolff sees Rousseau as "The most ambitious defense of majoritarianism in the literature of democratic theory" (Wolff 1998, 48). In brief, that majority rule is legitimated in its reflection of the general will "to issue commands which have the form of law and aim at the general good (Wolff $1998,53)$. However, Wolff argues that there is no reason to assume that the majority opinion on a given issue actually reflects what the general good is for a political community (Wolff 1998, 54-55). Since it is necessary for majority rule to always favor the general good in order to be morally legitimate, the very obvious question remains of why one would assume so (Wolff 1998, 56). As such, majority rule offers no real solution to the stability of morally legitimate political obligation, as it consistently must compromise the autonomy of dissenters (Wolff 1998, 57-58).

With Wolff's argument fleshed out, we can begin to understand how it reflects each of the characteristics of philosophical anarchism outlined above. First and most evident is the conclusion that political obligation is morally illegitimate. Through his analysis of the concepts of political obligation and autonomy, Wolff concludes that there is an unresolvable conflict between these two concepts as well as an impossibility to practically resolve this conflict, resulting in the impossibility of morally legitimate political obligation. So determined is Wolff in this conclusion that he believes the concept of morally legitimate political obligation "must be consigned [to] the category of the round square, the married [bachelorette], and the unsensed sense-datum" (Wolff 
1998, 71). As such, Wolff argues that citizens are not morally bound to obey the state, and are morally permitted to deliberate and determine for themselves how they ought to act (Wolff 1998, 13). Finally, these conclusions do not entail the absence of moral obligation, and that these obligations can often lead one to act in a way consistent with the obligations demanded by the state (Wolff 1998, 9). As such, it should now be clear why Wolff's arguments are placed in the camp of philosophical anarchism.

With this analysis of Wolff's arguments, it should also be clear how Wolff's argument advances an a priori approach to philosophical anarchism. Wolff consistently argues that the idea of morally legitimate political obligation is a conceptual impossibility, and as such there can never exist morally legitimate political obligation. Simply put, the moral illegitimacy of political obligation is a priori true independently of any practical considerations. Wolff furthers this conclusion by demonstrating that even some of the most committed democratic models to autonomy still cannot resolve the conceptual conflict between political obligation and the moral authority of autonomy. As such, Wolff's argument can be classified as an a priori approach to philosophical anarchism as it concludes that morally legitimate political obligation is an impossibility and cannot exist.

\subsection{A. John Simmons and A Posteriori Anarchism}

The next argument in favour of philosophical anarchism that I will analyze will be A. John Simmons's argument found in his essay "Justification and Legitimacy" (2001). To understand Simmons's argument, I will be analyzing his arguments in much the same 
way as I analyzed Wolff's. That is to say, I will begin by first analyzing the concepts that lie at the heart of Simmons's argument, in this case the justification and legitimacy of the state. I then outline his arguments that a Lockean approach provides the greatest potential for laying the groundwork for morally legitimate political obligation. I then analyze his conclusion that a strict adherence to voluntarism theoretically results in the moral legitimacy of political obligation, but that it has as of yet not been realized.

Afterwards, I show how Simmons's argument reflects the characteristics outlined in Part 1 , validating the conclusion that his argument is philosophically anarchist. Finally, I show how Simmons's argument reflects an a posteriori approach to philosophical anarchism.

Simmons's argument for the moral illegitimacy of political obligation is premised upon a very important distinction between the justification of the state and the legitimacy of the state. For Simmons, these two concepts describe two very different ways of understanding the role of the state. Simmons understands the concept of justification for anything as a defensive concept; that is, justification involves "rebutting certain kinds of possible objections to it" (Simmons 2001, 123-124). This includes showing that what is being justified is either prudentially rational or morally acceptable, or both (Simmons 2001, 123). Justification, as such, is necessary when there exists a possible objection against something's being prudentially rational or morally acceptable (Simmons 2001, 124). As such, Simmons argues that justifying either the actions or the existence of the state entails showing that it can counter arguments against the state's being prudentially preferable to "nonstate alternatives" or morally permissible 
(Simmons 2001, 125-126). Providing such counter arguments would entail appealing to certain general qualities or virtues that a state possesses over other alternatives (Simmons 2001, 136). Justification of the state, understood this way, would also present reasons not to undermine the state, and to typically support the state (Simmons 2001,

The legitimacy of the state, for Simmons, means something very different from the justification of the state. The legitimation of the state entails showing that the state possesses "the complex moral right ... to be the exclusive imposer of binding duties on its subjects, to have its subjects comply with these duties, and to use coercion to enforce these duties (Simmons 2001, 130). ${ }^{3}$ In this sense, legitimation seeks to vindicate a particular moral relationship between things; applied to the state, it is a demonstration that political obligation to the state is morally sound. Legitimacy of the state, thus, confers upon the state a moral right to a citizen's obedience, obligating the citizen to the state's laws and policies (Simmons 2001, 137). For Simmons, legitimacy of the state is necessary to morally ground a citizen's obligation to accept the authority of the state and to obey the laws and policies it enacts (Simmons 2001, 136). In other words, legitimacy of the state would result in making political obligation a morally compulsory obligation. For Simmons, political obligation to a state may only follow from

\footnotetext{
${ }^{3}$ This will be my only mention of the possibility of legitimate state coercion. My primary concern is to provide a literature review of philosophical anarchist approaches to political obligation, that is, the moral illegitimacy of obligations to the laws and policies of the state, and not how the state may respond to transgressors.
} 
the state possessing a moral right to our obedience, which is to show the legitimacy of the state.

Simmons provides an analogy to better understand the distinction between the justification and legitimacy of the state, and to show that the latter does not follow from the former. There may exist a business that engages in perfectly ethical practices, whose existence isn't morally offensive, and provides a worthwhile service to those it serves (Simmons 2001, 136). However, to say that that business is owed our loyalty and that we ought to only purchase the services it offers is quite a different matter, and not accounted for with the description above. The description of the business outlined above is one the accounts for the justification of the business; it demonstrates the moral permissibility and the prudential rationality of the business (Simmons 2001, 136). The type of argument that would demonstrate that the business is owed our unwavering loyalty is one that would account for the legitimacy of such loyalty. That is, it must demonstrate that the business possesses the right to our obedience. For Simmons, the difference between the justification and the legitimacy of the state is encapsulated by this analogy (Simmons 2001, 136). A state may be demonstrated to be morally permissible or prudentially rational, by say, governing in a manner morally permissible and providing benefit to its citizens, but political obligation to the state would require more than mere justification (Simmons 2001, 137). Such an explanation would be one explaining the legitimacy of the state's right to our obedience.

Simmons then uses this understanding of the legitimacy of the state to argue that influential arguments in favour of political obligation fail to actually provide an 
account of state legitimacy. The first argument that Simmons discusses is the Weberian view held by many, whereby a state is considered legitimate if it is generally approved of by its citizens (Simmons 2001, 131). To this account, it is the beliefs and the attitudes of the citizenry that determine the legitimacy of the state; if the citizenry feel as though they have a political obligation to the state, then the state is legitimate (Simmons 2001, 137). Simmons identifies two problems with this line of legitimation. Firstly, by shifting the focus to the citizenry, nothing about the state is being identified as a reason for its legitimation (Simmons 2001, 133). For Simmons, to "call a state legitimate is surely to say something about it, about the rights it possesses or the scope of its authority" (Simmons 2001, 133). A focus on the citizenry, however, does not provide such an account. Secondly, Simmons argues that states can, and some have been able to, engender feelings of extreme loyalty and obligation by way of propaganda, immense social control, and/or exploiting the ignorance and prejudices of its subjects (Simmons 2001, 134). Further, such states seem to be paradigm examples of illegitimate states, where few but the most indoctrinated would bother to argue otherwise (Simmons 2001, 134). ${ }^{4}$ For this reason, Simmons dismisses this Weberian view of legitimacy for failing to demonstrate the nature of the state which confers to it the right to political obligation.

The next argument Simmons discusses is the argument that the benefits a citizen receives from the state, and the state acting justly towards them are, in fact, the very foundations of the plausibility of political obligation. This view places the "moral quality" of the state in how it interacts with its citizenry; that is, on that understanding

\footnotetext{
${ }^{4}$ Consider North Korea.
} 
state legitimacy "consists in or is largely constituted by the sum of its morally significant relations with individual subjects" (Simmons 2001, 139). Thus, a state is legitimate if it treats its citizens justly and/or provides worthwhile benefits to its citizens. Simmons's objection to this account of state legitimacy is quite simple. Just because one is being treated justly, or receiving unsolicited benefits, does not obligate that person to the one (or group) that treats them so (Simmons 2001, 139). The same, Simmons argues, is true of the state; simply that the state behaves morally or benefits its citizens (no matter how immensely) cannot obligate the citizens to the state. As such, this approach to state legitimacy fails to properly ground the right of the state to political obligation, and thus fails to properly provide a legitimation of the state.

Simmons then discusses Kant's approach to state legitimacy. Kant's approach argues that both the justification and the legitimacy of the state rest on the same premise; that the state is necessary for the realization of rights and freedoms. Simmons summarizes Kant's argument as follows: everybody has basic rights and these rights can only be guaranteed if everyone accepts the state, thus, in order to exercise our own rights and to respect the rights of other, we are obligated to obey the state (Simmons $2001,140)$. For Kant, anyone who rejects obligations to the state jeopardizes the safety and security of the rights of others by undermining the state, which is necessary for their rights. Simmons, however, argues that the claim that obligation to the state is necessary to meet our moral obligations is not necessarily plausible (Simmons 2001, 140). For Simmons, it is not at all apparent that treating others morally and respecting their rights necessarily requires the state. Additionally, should a citizen decide not to 
recognize (even openly) the authority of the state, thus refusing political obligation, but still respect humanity, then it is not at all clear that the rights of others are in jeopardy (Simmons 2001, 141). In short, Kant's key premise is a dubious one and open to objection.

The final argument that Simmons analyzes is Rawls's argument for the legitimacy of the state. Simmons understands Rawls as presenting an argument that provides the principles which will satisfy "the need for some collective/economic solution by which all will subsequently be bound" (Simmons 2001, 143-144). That is, that the principles that will dictate how the constitution and its legal systems will function. For Rawls, these principles must provide "public justification"; that is, they must be shown to be morally acceptable in a way that is justifiable to all those that will be subject to the state (Simmons 2001, 143). Simmons understands Rawls's public justification of the state as consisting in "what is reasonable to expect [citizens] to accept - that is, in their hypothetical endorsement" (Simmons 2001, 144). However, Simmons first argues that Rawls's argument is too relativized, resulting in two problems with its ability to legitimate the state. The first objection made by Simmons is that Rawls's argument does not actually address the issue of state legitimacy and political obligation. Rawls develops his argument in a way that ignores consideration for non-state alternatives, where justification is based on the presumption that everyone accepts that they must be obligated to the state (Simmons 2001, 143). Thus, public justification serves to determine the structure of the state, but not why one ought to obligate themselves to it. This presumption makes the argument relative to those who have already accepted the 
moral legitimacy of states. Secondly, public justification is only offered to those who will be citizens of that state, and therefore, can only describe a particular state for a particular citizenry. Public justification will then represent not objective moral values, but rather the moral values of the citizenry in question (Simmons 2001,144$)$. Thus, the moral aspects of the state will be relativized to the moral values of the citizenry that public justification is offered to. For these reasons, Simmons argues that Rawls's approach to the state serves only to justify the state, though not even objectively, to the subjects that will fall under the state. ${ }^{5}$

Simmons argues that the only hope for state legitimacy and political obligation is a strict voluntarist approach inspired by Locke, though ultimately he concludes that no state satisfies such a conception of state legitimacy. For Simmons, the nature of political obligation is such that it is extremely personal, and must account for why particular individuals ought to obey the state, often ignored by more general accounts, such as hypothetical endorsement or public justification (Simmons 2001, 147). That is, given that an individual must accept the authority of the state, and cede any personal judgment of how to act in matters legislated by the state, an account of legitimacy must be applicable to any and all persons. Understood as such, we must seek to offer an account of legitimation that recognizes the very real relationship that individuals have with their states (Simmons 2001, 149). For this reason, the focus for demonstrating the

\footnotetext{
${ }^{5}$ It seems plausible that Simmons may be unfair in his exposition of Rawls's arguments, and it has been pointed out to me that Rawls's arguments are for providing the framework for allegiance which seems to be a very similar concept to political obligation. As with his analysis of Kant, my purpose here is to outline Simmons's arguments, and to critically discuss Simmons in my article.
} 
legitimacy of the state must be able to demonstrate something about the relationship between citizen and the state that reflects the personal nature of political obligation (Simmons 2001, 149).

Simmons argues that the best possible means for providing such a demonstration will be the voluntary consent of citizens to abide by the laws of the state, and to thus voluntarily accept political obligation. Simmons argues that given the extent of the impacts of political obligation on the citizen, pointing to a specific feature of the personal transaction between citizen and state is where one must look for state legitimacy (Simmons 2001, 147). Voluntary consent, for Simmons, is a clear demonstration of obligation, as it reflects how one has actually accepted how they will act, and as such accounts for the very "direct and personal" relationship entailed by political obligation. Much in the same way that making a promise is often considered a clear example of legitimate obligation to the promisee, voluntarily consenting to political obligation, for Simmons, clearly obligates one to their state. In this sense, legitimacy is a transactional evaluation, "grounded in morally significant features of the specific histories of interaction between individual persons and their polities" (Simmons 2001, 149). Therefore, voluntary consent to political obligation offers legitimacy to political obligation by reflecting the significant personal transaction between citizen and state.

To understand just how strictly Simmons understands the condition of voluntary consent, it will help to look at his arguments regarding consent found in Moral Principles and Political Obligation (Simmons 1979). There, Simmons argues that when consent is 
given, it is "given to the actions of other persons" (Simmons 1979, 76). Essentially, consent is an acceptance and authorization of the actions of another party, and gives that party a special right (Simmons 1979,76 ). For Simmons, consent must satisfy two conditions to truly reflect consent; it must be intentionally and knowingly given, as well as voluntarily given (Simmons 1979, 77). Apart from directly receiving the consent of the citizen, Simmons discusses tacit consent, which has traditionally been said to be appropriate for giving consent to the state. Simmons understands tacit consent as a way of consenting through inactivity, for which Simmons argues for five conditions to legitimate tacit consent (Simmons 1979, 80). Tacit consent must be such that the consenter is (1) aware that consent is appropriate, (2) given an appropriate period of time to voice dissent, (3) aware of when that period ends, (4) has the means to dissent in a way that is reasonably performed, and (5) allowed to dissent in a manner that does not result in extremely detrimental consequences (Simmons 1979, 80-81).

Simmons identifies, and argues against, two traditional ways of understanding how tacit consent is given by citizens to their states. The first is that by accepting certain benefits that the state provides, one has consented to the state (Simmons 1979, 84). However, Simmons argues that at best these acts may imply consent, but cannot definitively be used to determine tacit consent (Simmons 1979, 89-90). Particularly, Simmons argues that this approach understands the enjoyment of benefits as imparting the same set of obligations as though one had consented (Simmons 1979, 89-90). Simmons objects, however, arguing that this is not really an approach motivated by the value of consent, since it can hardly be clear that an individual has intentionally given 
their consent (Simmons 1979, 91). Rather, such an argument would necessarily have to be grounded on some other moral principle (Simmons 1979, 94). The second way in which citizens have been traditionally understood to have tacitly consented to their state is through residence (Simmons 1979,95 ). Simply put, by opting to continue residence in their state the citizen has tacitly consented to their state. Simmons objects to the notion of tacit consent by residence by arguing that it fails to satisfy conditions (4) and (5); that is, that the immense of difficulty of emigration makes the means of preforming dissent unreasonable and results in extremely detrimental consequences for the dissenter (Simmons 1979, 98). Emigration, for Simmons, is not only a practical impossibility for many people, but it also requires the sacrifice of some of the most important things that many people treasure in their lives, such as family, home, and friends. Thus, Simmons concludes that although tacit consent may be a possibility, the two most employed examples of tacit consent to the state fail to actually demonstrate consent.

Simmons goes on to argue that the only possible way obligation can exist without voluntary consent is when those obligations reflect the right of others that "we do our fair shares in contributing to acceptable levels of security and well-being for all" (Simmons 2001, 154). However, Simmons argues that there is no reason to assume that these "natural duties" can only be met by political obligation (Simmons 2001, 153). For Simmons, the notion that general moral obligations can only be met through political obligation is an empirical question, and one where no consistently true answer can be assumed (Simmons 2001, 154). It is not at all clear, Simmons argues, that an individual 
who rejects political obligation, but who still respects the rights of others by not undermining their security and privately contributing to their well-being, poses a threat to the rights of others (Simmons 2001, 154). Since the state has no natural moral claim to our obligation, Simmons concludes that the state is ultimately an "artificial human creation" (Simmons 2001, 155). Consequently, no matter how justified an artificial creation can be, it cannot claim from individuals a natural obligation to it; rather it can only be owed an obligation if an individual has voluntarily transacted with it in a manner that confers authority to the state (Simmons 2001, 155). For this reason, there is no obligation to the state that exists without the voluntary consent of those obligated.

For these reasons, Simmons reaches the conclusion that political obligation can only be morally legitimate "if either (a) we have directly interacted with the state in a way that grounds a special moral relationship of that sort, or if (b) accepting membership in a state is the only way we can fulfil one of our other moral obligations or duties" (Simmons 2001, 155). As has already been shown, Simmons argues that there is no obvious reason to assume (b) to be true, so we are left only with (a). As we have seen, Simmons argues that only voluntary consent can satisfy (a), as voluntary consent reflects the personal relationship between citizen and state entailed by political obligation. However, Simmons ultimately concludes that a strict voluntarist approach to political obligation results in the moral illegitimacy of all existing states, and thus, political obligation to them is not an immediate obligation. Simmons's argument for this is simple; there exists no state that satisfies the voluntarist criteria for moral legitimacy, therefore there are no morally legitimate states or unconsented obligations to them 
(Simmons 2001, 155-156). As such, the political obligation demanded by the state is morally unsound.

Simmons's argument possesses each of the three characteristics of philosophical anarchism. The first and most evident characteristic of philosophical anarchism reflected by Simmons's arguments is in the conclusion that the state's demands that citizens obey the state is morally unsound. Since Simmons identifies voluntary consent as the only grounds for legitimate political obligation, but all states enforce obligations without the full voluntary consent of all citizens, the state is morally illegitimate in its imposition of political obligation. Since citizens can only be obligated without consent when it is necessary for the fulfilment of other moral obligations, Simmons's arguments leaves citizens free to reject opting into political obligation since it is not apparent how political obligation is necessary for respecting moral obligations (Simmons 2001, 154). Lastly, Simmons argues that simply because existing states cannot legitimately claim political obligation from its citizens, we are not free from other general moral obligations. In fact, Simmons argues that justified states, though not being able to legitimately obligate us to its authority, can still warrant our moral support given the good they may do for other citizens (Simmons 2001, 156). As such, Simmons's arguments reflect all three characteristics of philosophical anarchism.

In contrast to Wolff's philosophical anarchism, it should be clear how Simmons's own argument takes an a posteriori approach to philosophical anarchism. Simmons does not argue that it is impossible for morally legitimate political obligation to exist; quite the contrary, he argues that morally legitimate political obligation can follow from 
voluntary consent. The philosophical anarchism of Simmons is the result of the premise that no state exists by the voluntary consent of all of its citizens to political obligation. In other words, there can be conditions in which morally sound political obligation exists, but states fail to meet those conditions, making their claims to political obligation morally unsound. Rather than arguing against the possibility of morally legitimate political obligation, Simmons argues that the concept of legitimacy can be reasoned out and has an important function for state evaluation. For this reason, Simmons's philosophical anarchism is the result of an a posteriori approach to the moral (im)plausibility of political obligation.

\subsection{Weak and Strong Philosophical Anarchism}

Before closing this section, it is necessary to outline the difference between weak and strong philosophical anarchism. Both of these approaches to philosophical anarchism have a different understanding of the moral weight of the moral implausibility of political obligation, each resulting in a different set of normative commitments. For these distinct approaches to philosophical anarchism, different conclusions follow from the nonexistence of morally sound political obligation. Namely, they make different conclusions on whether or not there exists an obligation to oppose the state or to work towards its elimination. Understanding the distinction between weak and strong philosophical anarchism is necessary to come to a more comprehensive grasp of how the philosophical anarchist understands the relationship of the citizen to the state. For this reason, I have chosen to devote this part of my 
literature review to outlining the difference between weak and strong philosophical anarchism as articulated by Simmons in "Philosophical Anarchism" (Simmons 2001).

Weak philosophical anarchism, simply put, is the view that the conclusion that political obligation is morally illegitimate provides no reason to oppose or to attempt the elimination of the state (Simmons 2001, 107). Further, the weak anarchist does not believe that an obligation to oppose the state can even follow from the argument that political obligation is morally illegitimate (Simmons 2001, 112). For the weak philosophical anarchist, the obligations demanded by the state are morally non-binding, but this conclusion can only suggest that the state is non-authoritative. As Simmons puts it, "weak anarchism says that we may regard the state as one more powerful bully whose commands and actions we may ignore where we can" (Simmons 2001, 107). This does not mean that the weak philosophical anarchist holds that a state ought never to be resisted or opposed, but merely that any such obligation will exist because of moral reasons independent from the illegitimacy of political obligation (Simmons 2001, 107). This weak approach to philosophical anarchism leaves the philosophical anarchist free to deliberate on how they ought to act, rather than prescribing a course of action that one ought to take (Simmons 2001, 108).

Strong philosophical anarchism, on the other hand, understands the moral illegitimacy of political obligation as providing reasons to oppose or to actively pursue the elimination of the state (Wolff 2001, 107). As such, strong philosophical anarchists understand the obligation to oppose the state as following from the argument that political obligation is morally illegitimate (Wolff 2001, 108). Although strong 
philosophical anarchists agree with weak philosophical anarchists that the state can be understood as a powerful bully, they also argue that the existence of such a bully obligates us to oppose them as. As Simmons puts it, "strong anarchism argues that all such bullies must be deprived of their power to coerce" (Simmons 2001, 107). It should be noted, however, that strong philosophical anarchism does not neglect other moral obligations in light of the obligation to oppose the state (Simmons 2001, 110). Other moral obligations may just as well trump the obligation to oppose the state when doing so jeopardizes the ability to uphold the moral obligations owed to fellow citizens. As such, the obligation to oppose the state can only exist when doing so does not conflict with general moral obligations owed to other citizens (Simmons 2001, 110). The strong approach to philosophical anarchism is different from the weak approach in that it actively obligates citizens to act in a certain way, to oppose the state, when doing so will not conflict with other moral obligations.

Understanding the distinction between weak and strong approaches to philosophical anarchism allows us to understand more comprehensively how philosophical anarchism views the nature of the citizen-state and citizen-citizen relationships. For the weak philosophical anarchist, the conclusion that political obligation is morally illegitimate results in no more than just that. Obligations owed to the state are morally nonbinding, but nothing more follows from this idea. As for the strong philosophical anarchist, the moral illegitimacy of political obligation obligates citizens to oppose and undermine their state whenever possible without neglecting other moral obligations. The moral illegitimacy of political obligation, for the strong 
philosophical anarchist, leads to the conclusion that certain normative implications follow from this moral illegitimacy. Despite this difference, both weak and strong approaches to philosophical anarchism can still be understood as philosophically anarchist as they still embody the three general characteristics of philosophical anarchism outlined in Part 1. Both of these approaches still conclude that political obligation is morally illegitimate, that this leaves the citizen morally unbound by the state, and that other independent moral obligations still exist. They do, however, lead to a different understanding of what the normative force of the moral illegitimacy of political obligation is, and for this reason, understanding the distinction allows us to understand how the philosophical anarchist views one's obligations with regards to the state.

\subsection{Summation on Philosophical Anarchism}

With the above review, it should now be clear on how we can understand philosophical anarchist approaches to political obligation. Philosophical anarchism is the conclusion that no morally legitimate political obligation exists, that citizens are free not to obey the state, while still advocating moral obligations to each other. From there, philosophical anarchism can be developed along two distinct argument types, the a priori and a posteriori approaches to the moral illegitimacy of political obligation. For Wolff, the moral illegitimacy of political obligation is a priori true, as autonomy and political obligation are contradictory concepts, with the former being the condition for moral legitimacy. On the other hand, Simmons argues that the moral illegitimacy of the 
state's claim to political obligation is a posteriori true, as only voluntary consent of every citizen can bring moral legitimacy to political obligation, but no state possesses (or seeks out) such consent. From there, there are two possibilities for the normative impact of the moral illegitimacy of political obligation, weak and strong philosophical anarchism. Weak philosophical anarchism argues that no normative commitments follow from the moral illegitimacy of political obligation, and that the moral illegitimacy of political obligation does not obligate anyone to oppose the state. Strong philosophical anarchism argues that an obligation to oppose the state does follow from the moral illegitimacy of political obligation so long as such opposition still reflects a commitment to the moral obligations that we owe to each other. With this review, we can understand the common conviction held by philosophical anarchists, how they might get there, and what they commit themselves to.

\subsection{Introduction to Participationism}

I will now turn to participationism to come to a clear understanding of what sort of democratic theory is proposed by participationism. To do so, I will focus on two key dimensions of participationist democratic theory: the moral and the practical. The moral and practical dimensions of participationism will illustrate the normative commitments participationist democracies ought to embody as well as the real-world democratic experiments which have been motivated by these commitments. As such, an analysis of the moral and practical dimensions is essential for understanding participationism as a distinct political philosophy and as a distinct ideal for democracy. 
For these reasons, analysing these two distinct, yet interrelated, dimensions of participationism will lead to a comprehensive understanding of participationism as a democratic theory.

In order to properly understand the moral and practical dimensions of participationism, I will devote specific subsections to each of these dimensions. In outlining the moral dimension of participationism, I draw on the influential work of Carole Pateman on the significance of participation for democratic theory. Here, I outline what I take to be the major commitments to the practice, defense, and development of autonomy as articulated by Pateman and her arguments regarding the normative values motivating a greater place for participation in democratic theory. Next, I analyse several contemporary experiments in participatory democracy in various aspects of social and political life from all over the world. There I will give brief overviews of the democratic processes that are employed and the effects that an increased role for participation have had in the democratic organizing and governing of many communities around the world.

After having analyzed both the moral and practical dimensions of participationism, I will give a brief summary of participationism and the democratic reforms that it is committed to. Here, I will show how the normative commitments outlined by Pateman, as well as the various democratic experiments in implementing a greater role for participation that I analyze, identify a distinct democratic theory and political philosophy with its own moral foundations and political prescriptions. It will be 
this distinct democratic theory that I understand as participationist, and with which I will engage in further study of its significance to philosophical anarchism.

\subsection{The Moral Dimension of Participationism}

Participationism as a contemporary democratic theory was first robustly illustrated and argued for by Carol Pateman. In Participation and Democratic Theory (Pateman 1970), Pateman outlines the pessimism towards participation present in many influential political theorists, the historical roots of participation's role in democracy, as well as its efficacy, potential, and real-world prospects. Most importantly for my project, however, is her discussion of the values that have motivated advocates of robust participation as a key component of democracy. Understanding these values is essential, as it will provide a full understanding of the normative commitments behind participationism. The values I have identified from Pateman's analysis of participationism are the practice of autonomy, the defense of autonomy, and the development of autonomy. As such, developing a moral and philosophical understanding of participationism, and by extension critiquing and analyzing it along those lines, will require an understanding of these values which identify its normative force.

My purpose here will be to outline Pateman's understanding of these three values. To do so, I will be analyzing Pateman's analysis of the role of participation in the arguments of Rousseau, Mill, and Cole. I will begin with a brief discussion on autonomy, but leave a more clearly defined notion of autonomy for after my discussion of the 
commitments made by participationism so as to understand what autonomy means to participationism. I will then turn to the commitments made by participationism with regard to autonomy, beginning with the practice of autonomy, to outline how participationism understands and embodies this value. Afterwards, I turn to Pateman's arguments that participation can serve as a means of defending autonomy, and participation's significance to democracy. Finally, I will give an exposition of Pateman's analysis of the role of participation in developing autonomy and educating people in exercising their autonomy. By analyzing these three values, I hope to have come to a comprehensive understanding of the normative appeal and force of participationism.

\subsection{Preliminary Comments on Autonomy}

Before turning to the normative commitments that participationism makes with respect to the autonomy of citizens, it will first be necessary to make some preliminary statements about autonomy. At first glance, it may seems easy to understand autonomy, and many political theorists have come to somewhat similar understandings of the concept. A simple understanding of autonomy commonly shared is the capacity for rational self-legislation. Despite its initial ability to clear confusion, several relevant questions follow from this simple definition. Namely, these are questions involving the extent to which autonomy ought to be valued in political and social life, how to respect the autonomy of others, how it is exercised, what its exercise entails, the measures necessary to ensure its preservation, and what efforts need to be taken to ensure citizens can actually develop their capacity for self-governance. It is in answering these 
questions that disagreements take place and competing understandings of autonomy are developed and advocated. For my purposes here, I have chosen to analyze how participationism answers these questions, thus analyzing the participationist's understanding of autonomy. I will postpone attempting a clear and coherent articulation of this understanding until after understanding the normative commitment of participationism, as understanding these normative commitments will help greatly in addressing many of the questions outlined above. With that in mind, I now turn to an analysis of these commitments.

\subsection{The Exercise of Autonomy}

In order to see how participationism can both defend and develop autonomy, it is necessary to first understand how participationism commits itself to a greater role for the practice of autonomy than other, more traditional democratic models. Simply put, participationism allows for the direct and equal participation of every citizen in the decision-making of the state (Pateman 1970, 43). Unlike in a representative democracy, where citizens periodically elect representatives on their behalf, participatory democracy places the power to make decisions in the immediate hands of the citizenry. Citizens discuss and debate issues and proposals, and then together make decisions about how their state will act. As such, all decisions made by the government are, in fact, the actual decisions of the citizenry and not decisions imposed on them by the state. By making political decisions via the participation of citizens, individuals are given 
the opportunity to practice their autonomy in a sphere of social life that directly affects them. $^{6}$

Participatory democracies are more fervent in their commitment to the exercise of autonomy than representative democracies for two reasons. Firstly, representative democracy fails to fully and actually represent the full spectrum of interests of the represented citizens (Pateman 1970, 37). In actuality, a representative can only represent the citizen's interests with respect to an explicit function or task; for example, an elected official at the municipal level can represent the municipal interests of the citizen, but not their federal interests. Additionally, should some unforeseen issue arise, the representative must act on what they believe to be in the citizens' interests, rather than the citizen being able to actually represent their interests in light of the unforeseen issue. This is inferior to the actual participation of the citizen as an expression of autonomy since the citizen cannot rely on a representative to represent all of their interests when engaged in decision-making. Secondly, representative democracy doesn't allow citizens to impact meaningfully on decision-making once a representative has been elected; they have been forced to surrender their autonomy until the next election (Pateman, 1970, 37). As soon as representatives have been elected, citizens are expected to allow themselves to be governed by those representatives and the decisions they make, rather than being able to govern and decide for themselves. As

\footnotetext{
${ }^{6}$ For my purposes here, it is not necessary to outline the precise model or framework that a democracy premised on the importance of maximum participation would actually look like. This is in large part due to the fact that the specifics of such a framework wouldn't be imposed on the citizen(s), but rather would be the product of how the citizen(s) themselves wish to structure such a system. The only constant would be the central focus on maximum participation of the citizens.
} 
such, representative democracy actually restricts the potential of individuals to exercise their autonomy by not being answerable to the actual interests of citizens, whereas participatory democracy is immediately answerable to the autonomy of citizens.

Most striking about participationism is the expansion of what is meant by the "political", and the expansion of participation in decision-making in other significant realms of social life. The most significant example of this expansion of participatory decision-making is at the workplace (Pateman 1970, 33-34). For the participationist, the citizen is not only affected by the government in their ability to practice autonomy in society, but also by the managerial structures present at work. That is, how citizens are able to govern themselves in society will be greatly impacted by their work life, and for this autonomy at the workplace is necessary for a truly participationist society. As such, the citizen under a participatory democracy would also be able to participate in the mechanisms that govern them at work. The result is that citizens can also be selfgoverning and express their autonomy in a sphere that directly impacts their day-to-day life. By allowing citizens to participate in the decision-making at work, the scope of their ability to be their own decision-maker of their own life is greatly expanded. ${ }^{7}$

It should now be clear how participationism understands the commitment to the practice of autonomy. Citizens should be given the opportunity to govern themselves in as many realms of their lives as possible. By having the decision-making function of

\footnotetext{
${ }^{7}$ Again, specifying the exact managerial structure or framework that would be at work here is not necessary. These structures would be the product of how citizens themselves wish to organize their work-life, not imposed from above. The only necessary component is the focus on the maximum participation of citizens.
} 
government immediately rooted in the participation of citizens, the resulting decisions which govern the individual are an expression of their own will. Also, by recognizing that citizens are also governed in their life by their work-life, and extending participatory democracy to work, citizens can be self-governors at work as well. In each sphere, participationism calls for citizens to be given a forum to express their own will and to have the decisions that most immediately affect them reflect and be the result of their will. With this in mind, we can now turn to how participationism both defends and develops autonomy.

\subsection{The Defense of Autonomy}

Participationism not only allows for individuals to exercise their autonomy, but it also provides various measures to protect the autonomy of citizens against possible infringements upon their autonomy. The first and most notable measure is that a participatory democratic structure would protect against the possibility of political decisions being to the sole benefit of a few at the expense of the many (Pateman 1970, 23-24). Since decisions are the product of every citizen deliberating on issues and proposals, citizens must rely on and cooperate with each other in order for any decision to get made and carried out. As such, the likelihood that a single citizen can pass laws to their sole benefit at the expense of others is very low (if not nil), since it is unlikely that citizens would accept such proposals. By having decisions be the result of everyone's participation, each must validate and justify their proposals to their fellow citizens; citizens are incapable of simply imposing their own will on others or forcing others to 
comply. The result is that citizens are given the forum and the ability to resist and reject proposals that would favor only one or a few at their expense.

Another measure against the infringement of autonomy that is the result of participatory democracy is that citizens will not be dependent on the autonomy of others for their own autonomy and would be only dependent on the participatory structure of government; in other words, that citizens are dependent on themselves and each other for their own autonomy (Pateman 1970, 23). In a participatory democracy, autonomy is not awarded after decisions have been made, or as the result of some group permitting it. Rather, the autonomy of citizens is recognized by the structure to be key component of decision-making, and as such, does not make autonomy dependent on the autonomy of others. The autonomy of citizens is presumed and guaranteed by participationist democracy, and left to the citizen to exercise and express. The only dependence for autonomy, then, under a participatory democracy is on the recognition that everyone has a right to autonomy and that consequently, the exercise of one's autonomy must depend on the equal autonomy of all. What results is that autonomy, consistent with equal autonomy for all, must provide a framework where each citizen is as dependent on each other as anyone else, and none less dependent than any other. As such, they are dependent only on participatory decisionmaking structures since this is where citizens can autonomously make decisions about the social impacts that affect their lives.

Despite these measures, there remains the question of how to resolve disputes between majorities and minorities and more specifically the dilemma of the tyranny of 
the majority. To understand how participationism attempts to resolve the tyranny of the majority dilemma, I will be looking at Pateman's arguments in The Problem of Political Obligation: A Critique of Liberal Theory (Pateman 1985). Here, Pateman recognizes that even a participationist decision-making model is still susceptible to possible infringements of autonomy as a result of majority rule. However, she argues that political disobedience has an important place in a truly participationist democracy, and that thus minorities ought to be allowed to reject the laws enacted by a majority (Pateman 1985, 162). For participationists, the obligation to abide by the decisions made must be created and self-assumed by citizens (Pateman 1985, 159). Since the obligation to obey the enactments of a participationist decision-making model must be one where it is self-assumed, it follows that citizens ought to be permitted to reject and disobey decisions that they oppose (Pateman 1985, 160). Pateman argues that a participationist society must view any political disobedience the same way it views any political activity (Pateman 1985, 162). That is, as an exercise of the autonomy of citizens to develop their political community. Further, Pateman argues that political disobedience also plays an important role in developing a participationist society (Pateman 1985, 162). To develop a just society which does not infringe on the rights of citizens, giving voice to those potentially injured by certain decisions is necessary, and sometimes the only means of expression may be disobedience. Since a participationist society ought to permit political disobedience, then citizens who find themselves in the minority are free to disobey and thus the tyranny of the majority would seem to pose no relevant dilemma for participationism. 
These commitments that participationism makes ensure that citizens are free to exercise their autonomy, and that their autonomy is not being compromised or neglected (Pateman 1970, 25). The autonomy of citizens will not be compromised by the decisions of a participatory democracy, since it is (near) impossible for one or a few to pass legislation to their sole benefit, or at the expense of the autonomy of everyone else. This ensures that citizens have control over what decisions are made, and that their control over decision-making will not be compromised. Additionally, a citizen has control of their own autonomy by not being arbitrarily dependent on some other group or system external to them. Rather, their autonomy is solely dependent on the equal autonomy of all and on the system that they themselves are a part of. Thus, participationism provides two critical commitments against the infringement of the autonomy of each and every citizen.

\subsection{The Development of Autonomy}

The final and perhaps most significant value behind participationism that I will look at is how a participatory democracy develops the autonomy of citizens. How participation aids in the development of autonomy can be seen as the most unique and motivating force behind participationism. It is unique in that no other democratic

model or structure seems to concern itself quite as much with the development of autonomy, or seems concerned about providing the means to educate citizens in their exercise of autonomy. This makes participationism particularly appealing, as it has the development of the citizenry as one of its main objectives and strongest effects. In this 
way, understanding how participation fosters the development of autonomy will allow us to understand a key moral and normative force at work in participationism.

The first way in which participationism develops autonomy is in fostering senses of civic virtue, allowing citizens to recognize and exercise autonomy in a way that is reflective, responsible, and respectful of the autonomy of others (Pateman 1970, 24-25, 29-30). By placing the citizen in a position where decisions are made collectively amongst their peers, and where proposals must be justified to all, the citizen must consider how others will respond to their proposals. By justifying a proposal a citizen may have, they are forced to consider how their proposal will impact other citizens and how others will react to it. This constant reflection over one's own interests and how they relate and impact the interests of others compel the citizen to think outside of their own self-interest and to see themselves as one among many engaged in a collective project. As such, attitudes that would approach democracy as a means of achieving one's own interests or that would place the interests of one over the interests of all are actively undermined by a participatory democratic framework. Instead, a participatory democratic framework provides a forum for citizens to learn how to exercise and understand their autonomy in relation to the equal autonomy of all others, fostering socially responsible exercises of autonomy. In this way, participationism helps the citizen to develop and educate their autonomy to be civically virtuous, rather than alienated from, and in competition with, fellow citizens.

Further, in a participatory democracy citizens also develop their autonomy to be politically efficient; that is, to possess the relevant knowledge and experience to 
efficiently govern themselves in their social and political lives (Pateman 1970, 38-39). By allowing citizens to actually participate in decision-making structures, they become familiar with the actual processes that are used to make decisions. This is in stark contrast to decision-making models that place little to no emphasis of the active participation of all of those affected by its decisions. By placing political and social decision-making out of reach from most of the citizenry, the structure and process for political and social organization is made alien from the lives of citizens. For this reason, there is little chance for the citizenry to actually learn how their society is practically organized and how decisions that impact their lives are made. Under such models, it is hard to imagine how citizens can develop their autonomy in ways that can allow them to be politically effective. If citizens are never, or very limitedly, familiarized with the actual structures and processes of social and political decision-making, then it would seem unreasonable to expect them to practice their autonomy in socially or politically effective ways. Democracies which solicit the active participation of citizens, on the other hand, do not face this problem. Citizens, by actually participating in social and political decision making, are directly exposed to and given the experience necessary to learn how to exercise their autonomy in socially and politically efficient ways. Rather than the structures and processes of decision-making being alien from most citizens, participationism makes these processes and structures a relevant aspect of citizens' lives.

Finally, the development of autonomy to be civically virtuous and politically efficient, along with the practice and defense of autonomy outlined above, results in the 
most crucial aspect of the development of autonomy: the capability to actually be a selfgovernor (Pateman 1970, 45-46). By engaging in an active commitment to the practice and defense of autonomy, while fostering the development of the autonomy of citizens, citizens are freed from over-dependence and reliance on others to govern them. Rather than making citizens passive towards or servile to decision-making processes, these processes become the expression of the autonomy of citizens. Additionally, participationism provides the framework to allow citizens to be confident in their own autonomy. By developing autonomy to be civically virtuous and politically efficient, as well as insuring the forum to practice and the means to defend their autonomy, the citizen can feel secure in exercising their autonomy free from marginalization or notions of inability to participate. The citizen, in a participatory democracy, is provided with all the necessary political and social means to feel confident in their autonomy and ability to be self-governors. Participationism actively seeks to provide citizens with the means necessary to practice and defend their autonomy and to develop their autonomy to its fullest potential in ways that are responsible and efficient. This allows the citizen to actually develop their capacity to be confident, responsible and efficient self-governors of their own lives, rather than servile or deferential to others.

The importance that the development of autonomy plays within participationism should not be under-valued. The notion that the citizenry's ability to self-govern ought to not only be allowed and defended, but actively developed and educated, lies at the heart of participationist democratic theory (Pateman 1970, 42-43). Rather than seeing political or social institutions as simply being a means of organization and coordination, 
participationism sees the incredible opportunity that these institutions can have for developing and fostering the autonomy of citizens, and by extension, a true democratic society, should participation in them be granted. It is the commitment to the development of autonomy as a key value of a properly democratic society that truly makes participationism a unique democratic theory that stands apart from the rest. Thus, an analysis of participatory democratic models must always be mindful of how it develops the autonomy of citizens to be civically virtuous, efficient, and confident to properly understand the normative force behind participationism.

\subsection{Autonomy, Properly Understood}

All of the above commitments can be used to develop a particular notion of autonomy that participationism commits itself to. By committing itself to the provision of a forum for the practice of autonomy, we can conclude that participationism understands autonomy as not simply something that people have, but something that people do. That is, people are autonomous when they are truly capable of exercising their autonomy. Additionally, by analyzing the commitment to defending the autonomy of each citizen, it is clear that autonomy is viewed as not simply valuable, but also that each person's autonomy ought to be equally valuable to all others'. No one person's autonomy ought to override or take precedence over any other. Lastly, by looking at the commitment to education and development, participationism understands autonomy as a source of immense potential that can enrich the lives of every person, and that every person, when given the proper care, is capable of this enrichment. There 
is no forum where a person's autonomy cannot be valuable so long as they are given the possibility to develop their autonomy, which in turn enriches their own capacity for autonomy. As such, we can conclude that the participationist provides a robust understanding of what it means to be autonomous; it is way of acting and behaving that reflects one's own interests which is equally valuable to any other person that not only enriches one's own life but also, given participatory governing models, enriches everyone's life and by extension society.

\subsection{The Practical Dimension of Participationism}

I turn now to an analysis of practical, real-world examples of participationism. The purpose of this discussion is to provide some sense of what practical commitments follow from the normative commitments of participationism. By analyzing these real examples of participationism at work, and the practical commitments they embody, a more comprehensive idea of what participationism is can be developed. Additionally, an overview of some participationist models can provide fruitful analyses of the efficiency of these models, with respects to both effective governing and to their ability to achieve its moral goals. For these reasons, looking at real-world participationist models is invaluable to understanding and evaluating participatory democratic theory.

To best understand the type of practical commitments made by participationism, I have selected three examples of participationism at work in three distinct and 
significant realms of social and political life. ${ }^{8}$ First, I look at the participatory

mechanisms that govern developmental budgets in the Indian state of Kerala to see how participationism can govern finances on a large scale. Secondly, I look at the participatory initiatives in Chicago's public school system and police force to understand how participationism has organized and impacted community planning and oversight. Lastly, I turn to worker owned and managed factories in Argentina, particularly the Zanon textile factory, to understand participationist approaches to workplace management. By looking at these participationist approaches to budgeting, community planning, and workplace management, I hope to provide a firmer grasp on how participationism envisions the governing structures that follow from its moral commitments.

\subsection{Participatory Budgeting in Kerala, India}

The Indian state of Kerala has been home to one of the most robust experiments in participatory democratic governing structures in the world. Since $1996,40 \%$ of state funds allocated to developmental aid has been governed by a variety of local selfgoverning institutions (Isaac and Heller 2003, 78). These local self-governing institutions (LSGIs) include urban municipalities as well as rural districts, blocks, and village councils known as Grama Panchayats (Isaac and Heller 2003, 78). At least two to

\footnotetext{
${ }^{8}$ I do not mean to say that these three realms of social and political life are the only relevant realms to understanding a participatory society, nor that reform of these realms towards participationism is sufficient for a participatory democracy. Reforms to institutional sexism, racism, classism, religious supremacism, and much more will also be necessary. They are, however, significant realms of social and political life where real experiments in participationism have taken place, and it is for this reason that I focus on them.
} 
four times a year in each of these LSGIs, assemblies known as Grama Sabhas are held where citizens can voice their views on what issues they feel need to be addressed and develop priorities of where they feel developmental funds should be allocated (Isaac and Heller 2003, 84, 90-91). To facilitate this process, the Grama Sabhas are divided into smaller groups which address a particular sector of development (Isaac and Heller $2003,91)$. These sectors then form development seminars to make reports addressing the specific needs identified during the assembly, to assess the available resources, and to construct a local development strategy based on those reports (Isaac and Heller $2003,84,92$ ). From these development seminars, task forces are formed to prepare concrete project proposals based on the development strategies determined by the development seminars (Isaac and Heller 2003, 84, 93). The proposals made by these task forces are then integrated with each other, first at the grass-roots tiers of municipalities and panchayats then at the higher tiers of district and block, to form a coherent development plan for each LSGI (Isaac and Heller 2003, 84, 93-94). Finally, the development plans are then appraised for technical feasibility by Voluntary Technical Corps made up of professional volunteers from various relevant fields, which make recommendations based on their expertise and the goals of the development strategy. The resulting development plan is then presented to Grama Sabhas where projects are explained and defended. 
The participatory budgeting model employed by Kerala embodies each of the normative commitments of participationism in important ways. ${ }^{9}$ Firstly, Grama Sabhas provide the forum for the participation of all citizens to express their thoughts and interests regarding their social and political life, rather than to simply defer their autonomy to elected representatives (Isaac and Heller 2003, 102). Most striking about Kerala's participatory budgeting model in this respect has been the conscious solicitation of traditionally disenfranchised segments of Indian society which include women and Scheduled Tribes and Castes (Isaac and Heller 2003, 92). These groups that were traditionally left out of deliberations on determining development budgets have been given not only the forum but also the legal right to actively participate in the planning process via the Grama Sabhas (Isaac and Heller 2003, 92, 102, 105). Thus, the Kerala experiment is a paradigm example of the commitment to the practice of autonomy for each of its citizens by providing the forum for the equal participation of all of its citizens in Grama Sabhas.

Secondly, the Kerala experiment has also provided important safeguards for the autonomy of its citizens in both respects outlined earlier. Once a development strategy has been outlined by a development seminar, which is the product of the Grama Sabha, all ascending levels of the planning process must remain true to that strategy (Isaac and Heller 2003, 93, 95). At no point are the ascending levels of planning permitted to stray too far or to drastically reformulate the intentions and goals outlined by the previous

\footnotetext{
${ }^{9}$ I don't mean to say that the following evaluation reflects the entirety of Kerala's society or even budgeting procedure. To be specific, it would be with regards to $35-40 \%$ of Kerala's developmental aid budgeting.
} 
level of planning. Additionally, the Volunteer Technical Corps cannot change or augment the development plans they are asked to evaluate, and can only make recommendations. Lastly, each finalized development plan must not only be presented to Grama Sabhas, but also defended with regard to keeping up the intentions determined by the Grama Sabhas and their development seminars (Isaac and Heller 2003, 90). These precautions ensure that development plans actually reflect in important ways the autonomy of participating citizens, rather than the intentions of a few. This, in turn, reflects a commitment to producing a development plan that is not to the sole benefit of one or a few, but rather to the benefit of each participating citizen.

The structure of this planning process also ensures that citizens are not dependent on some alien process to grant them their autonomy or to produce a budget that is assumed to reflect the autonomy of the citizens. Rather, the planning process for Kerala's developmental aid budget is assumed to be dependent on, and the result of, the autonomous decision-making of each of its citizens (Isaac and Heller 2003, 86-87). The development seminars are made up of delegates nominated from and elected by the Grama Sabhas, and as such ensures that the seminars and resulting development strategies are made of citizens and reflect their autonomy (Isaac and Heller 2003, 92). The task forces made were further constituted in large part by ordinary citizens elected by the development seminars, and were restricted to the development strategy outlined by the development seminars (Isaac and Heller 2003, 93). And as noted above, the Volunteer Technical Corps, though made up of unelected professional volunteers, was given no power to change or augment the finalized development plan (Isaac and Heller 
$2003,95)$. These various measures ensure that citizens are dependent only upon themselves to participate with each other to develop and formulate budgets for developmental aid. As such, the planning process for developing a developmental aid budget is one that is made up of and reflective of the actual autonomy of citizens rather than some external group or process.

Lastly, the development of citizen autonomy to be politically efficient is also reflected by some of the measures taken by the Kerala experiment. The development sectors formed during the Grama Sabhas are facilitated by a trained and locally recruited facilitator, who helps those participating in that sector to analyze issues and problems (Isaac and Heller 2003, 91). This process familiarizes citizens with the rational process needed to analyze, work though, and develop strategies, and provides them with the experience needed to improve their capacity to do so. Additionally, the delegates chosen to make up the task forces, largely made up of ordinary citizens, also received specialized training given by the State Planning Board of Kerala on how to construct comprehensive project proposals (Isaac and Heller 2003, 93). This gives citizens the opportunity to actually learn what goes into making a project proposal that will determine the finalized development plan. Further, by working with and considering the input of the Volunteer Technical Corps, citizens familiarize themselves with the practical considerations and necessities that developmental projects must take into consideration to be realizable. All of these features of the planning process for Kerala's developmental aid budget ensure that citizens are not simply thrown into the fire, but rather are trained and learn how to be effective and efficient self-legislators. 


\subsection{Participatory Community Planning in Chicago, Illinois, U.S.A.}

The city of Chicago has implemented participatory reforms to both its school and police governing institutions which have allowed its citizens the ability to participate better in the decision-making structures that are of immense significance to their communities. In 1988, the Chicago School Reform Act was passed, which greatly decentralized the governance of schools and implemented measures to ensure that citizens can participate in the decision-making of school policy, including the hiring, evaluation, and dismissal of principals as well as school budgets (Fung 2003, 115). This act mandates that each of Chicago's (roughly) 540 elementary and high schools conduct local meetings every two years to elect six parents, two community members, two teachers, and a non-teaching staff to Local School Councils, which conduct regular meetings open to all community members (Fung 2003, 111, 113, 117; Local School Councils, Web). Local School Councils for high schools also have non-voting positions for students elected by the local school's student body (Fung 2003, 111; Local School Councils, Web). Similar to the reforms made in Chicago's public schools, the Chicago Police Department implemented the Chicago Alternate Policing Strategy, which implemented participatory reforms to local beat governance in 1995 (Fung 2003, 112). Regular meetings between patrol officers, sergeants, and community members are held in each of Chicago's 279 beats where public safety concerns are voiced and prioritized, and where strategies are developed and evaluated (Fung 2003, 112). For both Local School Councils and local beats, the relevant centralized authorities (Chicago Public Schools, Chicago Police Department, and the Mayor's Office) play a facilitative role in 
the participatory decision-making of schools and beats (rather than a more traditionally domineering role) which Archon Fung has called a system of "accountable autonomy" (Fung 2003, 112, 113). This system of accountable autonomy is accomplished by the relevant centralized authorities providing various training opportunities for Local School Council members and beat meeting facilitators, as well as mechanisms to evaluate the success and effectiveness of each local school council and beat strategy (Fung 2003, 119-120). When intervention is deemed necessary by the centralized authorities, however, it takes the form of increased facilitation and training of Local School Councils and beat meetings rather than revocation of participatory decision-making (Fung 2003, 134-135, 136).

The reforms taken by the Chicago Schools Reform Act and the Chicago Alternate Policing Strategy demonstrate a participationist decision-making model clearly reflecting the same normative commitments as participationism. In the case of Local School Councils, any local parent, teacher, community member, and non-teaching staff can run for a position on their Local School Council or simply attend the monthly meetings and voice their interests there, giving them ample opportunity to exercise their autonomy. As for local beat meetings, again, any community member is welcome to participate in the prioritization of safety concerns and the development of strategies to address these concerns. Both of these models for exercising autonomy have resulted in meaningful impacts on community governance that reflects the interests of each Local School Council or local beat. Many Local School Councils interested in restructuring the school day so as to allow teachers to collaborate and work on classes influenced the Chicago 
Board of Education to work into the collective agreement an allowance for schools to modify school schedules if the changes were supported by that school's teachers (Fung $2003,121)$. In many local beat meetings, drug houses were often determined to be top priorities, and so a strategy was developed by many local beats that mobilized citizens to work with the Chicago Police and Chicago Legal Departments in targeting landlords of known drug houses (Fung 2003, 121-122). This strategy influenced a city ordinance that facilitated the effectiveness of this strategy by empowering local residents, and it was enforceable by the newly created Drug and Gang House Enforcement Section of the Chicago Legal Department (Fung 2003, 122). In both of these cases, the relevant centralized authorities worked as facilitators of the interests and decisions made by the participation of citizens in local councils and meeting rather than as imposers of policy.

Both Local School Councils and local beats have also worked hard to defend the autonomy of citizens participating in decision-making. This is most clearly demonstrated in how Chicago Public Schools and the Chicago Police Department have addressed obstacles in participatory governance. In the case of one Local School Council, an inability to work together in addressing issues had exacerbated the already deteriorating conditions for one high school, including overcrowded classrooms, poor student test performance, inability to repair damages, and more (Fung 2003, 133-134). In response to the inability of the Local School Council to work together to address these issues, administrators were sent to facilitate council meetings, as well as to present a review of noticeable issues in the school and recommendations on how to address them (Fung 2003, 134-135). In under a year the Local School Council was able to overcome 
previous divisions and were able to work together in addressing the issues they faced (Fung 2003, 135). As for one local beat, issues arose where the concerns of the wealthy side of the beat disproportionately took priority of the poorer side which experienced more serious safety concerns (Fung 2003, 135-136). This was the result of the then elected beat-facilitator who worked on a first-come, first-serve basis of prioritization. This changed, however, when a newly elected beat-facilitator implemented reforms to implement "brain-storming spaces" where residents on both sides of the beats were able to construct a "beat plan" which described and justified the concerns raised (Fung $2003,136)$. The performance of this exercise resulted in a consensus that the issues faced on the poor side of town were of greater concern to the whole beat (Fung 2003, 136). Both of these examples demonstrate a clear commitment to the defense of the autonomy of all citizens from being overridden by competing interests and from dependence on external forces.

Lastly, both of these models have worked significantly to help develop the autonomy of participating citizens in being able to govern their own schools and beats. Chicago Public Schools as well as non-profit community organizations offer extensive training (some mandatory, some optional) to council members in matters such as principal selection, school budgeting, and teamwork (Fung 2003, 120). Of particular significance is the training council members receive in constructing an annual school improvement plan, in which they outline a three-year plan and the steps that will be taken to achieve those goals (Fung 2003, 118). As for local beats, training was given to local residents and patrol officers in deliberative problem-solving, allowing participants 
to be better come to a consensus and to develop strategies to address concerns fairly (Fung 2003, 120). The training offered to those participating or wishing to participate ensures that participants are able to work together, are familiar with the mechanisms to effect policy, and have the tools necessary to work within that mechanism. This allows citizens to develop their autonomy to be civically virtuous, effective, and efficient in governing important aspects of their community.

\subsection{Participatory Workplace Ownership and Management in Argentina}

In 2001, workers at the Zanon ceramics plant in Argentina took control of the factory after the owners had closed the factory and fired the workers with no back-pay or indemnities, setting a precedent for worker occupied and managed workplaces that many other Argentinian workers would replicate (Trigona 2008, 155). The workers at Zanon opted for a non-hierarchal, community based decision-making model as the management structure for the factory, allowing the workers to self-manage the factory (Trigona 2008, 157). This participatory management structure extends to all aspects of management, including, but not limited to, wages, safety measures, workloads, hiring, and production planning (Trigona 2008, 158, 159, 160, 161). To accomplish this style of management, regular worker assemblies take place where proposals are made and analyzed, and where votes are taken to make decisions (Trigona 2008, 161). The work environment, previously rigidly managed with fraternization between workers from different factory lines strictly prohibited, was drastically restructured so as to facilitate communication and socialization amongst all workers (Trigona 2008, 158). The worker- 
controlled Zanon factory was able to weather the Argentinian financial meltdown in late 2001 , produced 410,000 square meters of ceramic tiles as of 2006, employs 473 workers as of 2008 , and has continued to compete successfully in the domestic market (Trigona $2008,157,160,161)$.

Regular worker assemblies embody the importance of practicing autonomy in decision-making by providing a forum for all workers to participate in the management of Zanon. This commitment is embodied by the factories founding concept of "autogestión", meaning that "manual and intellectual production is divided equally to benefit all collective members" (Trigona 2008, 161). This ideal enforces and motivates a commitment to participatory management where each worker has autonomy at their workplace and can impact managerial decision-making. Additionally, to combat issues related to institutionalized sexism and to give women a space to discuss the issues and develop strategies to overcome sexism, women workers at Zanon created the Women's Commission (Trigona 2008, 160). By providing spaces for discussing prejudices in the workplace, publishing newsletters to inform workers of these struggles, and addressing needs for social services, such as daycare, the workers of Zanon are given resources to combat traditional obstacles, in this case sexism, to the full inclusion of all workers in decision-making (Trigona 2008, 160-161).

The creation of Zanon's Women's Commission also represents a clear attempt to defend the autonomy of women from traditional systems of prejudice. The ability to directly confront institutionalized systems of oppression, to analyze them, and to take measures to undermine them provides real strategies for workers to defend their 
autonomy against infringement. Two other means of defending the autonomy of the workers at Zanon have also been taken. Firstly, the workers at Zanon have engaged in lengthy legal disputes so as to be recognized as a legally legitimate entity and to win the right continue the cooperative running of the factory (Trigona 2008, 156). Secondly, although the advice of professionals, such as lawyers or accountants, is frequently solicited, these professionals have no authority in the adoption of plans or policies leaving decision-making in the hands of the workers (Trigona 2008, 161). Both of these measures ensure that the autonomy of workers in their decision-making remain their own and not dependent on others.

Lastly, the practice of participatory management under the notion of autogestion has given workers the opportunity to learn all of the aspects related to efficiently and effectively managing a workplace. This has included experience in coordinating systems of production and bookkeeping, with the formation of various commissions to nominate a regularly rotating coordinator who regularly meets with other coordinators and reports back to the commission (Trigona 2008, 160). This experience has allowed workers to familiarize themselves with all of the relevant mechanisms and knowledge necessary to make informed decisions in participating in workplace management. Additionally, the bookkeeping coordinator presents the monthly general assemblies with a report on the finances of the factory, exposing the workers to the experience of learning how to manage the finances of the factory (Trigona 2008, 160). Lastly, the reversal of strict policies against fraternization between 
workers exposes workers to the interests and views of their fellow workers, fostering senses of civic virtue and collective interests.

\subsection{Summation on Participationism}

An understanding of participationism should now be readily available. It is an ideal for democratic governance which actively pursues the robust participation of citizens in the decision-making structures that affect them. This ideal is premised on the normative commitments to the expression of citizen autonomy, defending it against infringement or dependence to others, and to facilitating its development so as to fully enrich the lives of citizens in a way in which the autonomy of each citizen is respected, protected, and promoted by all. These commitments are reflected in providing forums such as councils or assemblies to allow citizens to voice their interests and develop the means to develop and work out policies and strategies. These forums provide citizens with the means to protect their autonomy against possible infringement, often resulting in specific measures to address disenfranchisement and to ensure that everyone has the ability to participate. Lastly, participationist models of decision-making have ensured that participants are not only provided with the ability to familiarize themselves with the actual decision-making mechanisms that affect them, but that training them in the technicalities of relevant aspects of decision-making increases their effectiveness to selfgovern. 


\section{Article: A Participationist Approach to Philosophical Anarchism}

\subsection{Introduction}

Philosophical anarchism is best reflected in its conclusion that there is no legitimate state. In contemporary political philosophy, this position was first developed by Robert Paul Wolff in his influential essay In Defense of Anarchism; however, others have since gone on to develop other approaches to philosophical anarchism. The most notable development in philosophical anarchism has been the voluntarism of A. John Simmons. Simmons's arguments have been seen as a response to the shortcomings of Wolff's arguments. Despite the supposed strengths of Simmons's voluntarist approach to philosophical anarchism, significant problems with his argument remain. For these reasons, it would seem that voluntarism does not suffice in evaluating the legitimacy of states. Does this, however, mean that philosophical anarchism is also problematic? Or is there still a way that philosophical anarchism can be defended?

I intend to develop a participationist approach to philosophical anarchism. To do so, I will begin with an analysis of the main concepts that will be necessary to develop such an argument: the state, political obligation, and moral legitimacy. Afterwards, an exposition of two distinct philosophical anarchist arguments, a priori anarchism and $a$ posteriori anarchism, will be given by focusing on the arguments of Wolff and Simmons. Following this, an evaluation of these arguments will be given, concluding that although Simmons's arguments are more plausible than Wolff's, they are not without shortcomings. To overcome these shortcomings, a shift from voluntarism to 
participationism will be necessary. To understand this shift, a brief overview of participationist democratic theory will be provided. From there, I will show how participationism embodies the same value of autonomy motivating voluntarism while sharing none of its shortcomings as a condition for the moral legitimacy of the state. A possible defence of Simmons's voluntarism will be considered, where participationism simply reduces into voluntarism. It will be shown, however, that participationism provides a unique criterion for legitimacy, by stressing the importance of active citizen engagement. Finally, the argument that philosophical anarchism follows from participationism will be outlined and defended against an objection by Carol Pateman. These arguments will show that a participationist approach to philosophical anarchism is sound.

\subsection{Understanding the Concepts}

There are three concepts that I will focus on here which are central to understanding contemporary philosophical anarchism: the concepts of the state, political obligation, and legitimacy. Robert Paul Wolff understands the state as "a group of persons who have and exercise supreme authority within a given territory or over a certain population" (Wolff 1998, 3). Similarly, A. John Simmons argues that the state is that which possesses a "complex moral right ... to be the exclusive imposer of duties, to have its subjects comply with these duties, and to use coercion to enforce these duties" (Simmons 2001, 130). These two definitions of "state" provide insight into identifying 
significant features of the state. Wolff's proposal that the state is made up of a group of persons seems intuitive enough, and this proposal only becomes more plausible by including another commonly held intuition that a group of persons who together form various institutions constitute a state. ${ }^{10}$ Further, Wolff's understanding that the state is a territorial body is also intuitive enough to be accepted. Additionally, by leaving aside the undefined concepts of moral rights and coercion, Simmons's understanding that the state is the exclusive imposer of duties, or more clearly, laws, also makes the notion of a state clearer. Putting all these ideas together, I propose the following definition for a state: a group of persons who together form various institutions which are the exclusive imposer of laws within a given territory.

Political obligation is the obligation of citizens to obey the state's laws and policies. To better understand the notion of political obligation, it is helpful to understand authority and what it means for a state to possess authority. Wolff defines authority as "the right to command, and correlatively, the right to be obeyed" (Wolff $2001,4)$. What is important to note is that "authority" is being understood here as a normative concept, rather than simply as a descriptive concept. To make this clearer: authority conveys the notion that moral obligations are at play, specifically, the moral obligations to obey the commands of the authority in question, and that the state does no wrong in making such commands. Considering the definition of "state" outlined above, I propose that for the purposes of this argument, by "authority" we can mean

\footnotetext{
${ }^{10}$ Although these institutions can vary, I have principally in mind political/regulative, legal, and economic institutions.
} 
that the state has the right to impose laws and to expect those laws to be obeyed. This mirrors Simmons's belief that a vital component of the state is the right "to have its subjects comply with [its laws]" (Simmons 2001, 130). Put another way, to say that the state has authority is to say that the laws which a state imposes have authoritative force; that is, the state is owed political obligation.

Understanding the normative nature of authority can be made clearer by comparing it to simple power. Wolff makes this distinction clear, defining power as "the ability to compel compliance, either through the use or the threat of force" (Wolff 1998, 4). Here, power is being used as descriptive concept. A mugger who pulls a gun on me may have the power to take my money away, but it would be ridiculous to assume that the mugger has the authority to act in such a way (Wolff 1998, 4). What this example illustrates is that the mugger's demands, despite my compliance, would have no real normative force; I am not morally obligated to hand my money over to him. Only those demands which I have a moral obligation to obey can be said to have authority over me. Thus, the state has authority if, and only if, I have a moral obligation to comply with its demands.

As both Wolff and Simmons argue, however, it is also important to note that obedience to the state has to be the result of the state itself to specifically say that the state is authoritative. As Wolff notes, authority must be distinguished from persuasive argument (Wolff 1998,6$)$. If demands are made of me, and after careful deliberation and consideration of reasons given, I choose to comply, then I act on the authority of my own understanding of what my obligations are (Wolff 1998,6). Likewise, Simmons 
argues that there can be many moral reasons for me to act in certain ways, and the state may happen to demand that I act in those ways, but my acting morally is the product of moral reasons, not the state (Simmons 2001, 153). Although it is clear that basic principles of morality can have authority over me, it does not follow that the state has authority over me. In order for the state to be truly authoritative, my compliance must be the result of the normative force of the state's impositions of laws. Thus, political obligation to the state follows from the authority of the state over the individual.

Legitimacy is the key concept which has the most implications with regards to the concepts of the state and political obligation. Properly fleshed out, this concept could potentially provide a means of morally justifying the existence of a state which has authority, or not. This is why the question, "Is the state morally legitimate?" is such an important one, and hugely significant for a philosophical evaluation of the political. Only by coming to a clear understanding of the concept of legitimacy can we hope to give any kind of philosophical evaluation of states and political obligations to them. I propose that we can understand the concept of legitimacy when we analyze what takes place when we evaluate the demands made by some of others. Many people may demand my obligation, but that does not necessarily mean that they are in fact owed my obligation. When these demands are evaluated, and determined to be plausible or sound, then we can understand those demands as legitimate. On the other hand, if after evaluation these demands are neither plausible nor sound, then those demands are illegitimate. As such, I understand legitimacy as a concept used when evaluating 
demands to classify which are concluded to be plausible or sound. Conversely, I understand illegitimacy as a concept used when evaluating demands to classify demands which are concluded to not be plausible or sound.

To understand how the classification of legitimacy can be applied to states, we can use Wolff's understanding of de facto states. A de facto state is one that claims to be a legitimate state, possessing legitimate claims to my political obligation, and possesses a monopoly of force to compel compliance (Wolff 1998, 5). In this sense, we can understand the concept of de facto states as one of mere description; it merely describes what a state looks like. However, as noted above, whether or not these claims are in fact legitimate doesn't follow from their mere declaration. A justification must be given to accept these claims if they are to be legitimate, and if no justification can be adequately and convincingly given, then the claims will be illegitimate. As such, when we seek to determine the legitimacy of states, we seek to determine whether the claims and demands of de facto states can be adequately and convincingly justified. Simply put, state legitimacy is the normative justification of the state's authority and political obligation to it.

An important distinction should be made here between normative justifications to obey, and pragmatic justifications for acts. To better understand the concept of pragmatic justification, we can evaluate what takes place when anyone is asked to justify a course of action that was undertaken. Simmons argues that "Justifying an act ... typically involves showing it to be prudentially rational, morally acceptable, or both" (Simmons 2001, 123). For example, if I'm asked to justify playing a video game instead 
of watching a movie, I can say that the two are not totally dissimilar, that I have a right to choose how I spend my leisure time, or both. Although I can justify my act, this sort of justification, once given, would not obligate you to either provide me the means to do so or that you ought to do the same as me; it carries no normative force. When applied to states, we can potentially offer similar sorts of pragmatic justifications which identify prudentially rational or morally acceptable acts, but these claims will have no normative force. Claims made on me to obey the state are normative by nature, and therefore, must provide more significant, normative justifications.

\subsection{Philosophical Anarchism}

Philosophical anarchism is the rejection of claims and arguments that states are morally legitimate. Within philosophical anarchist literature, there are two distinctive arguments for the illegitimacy of the state, a priori anarchism and a priori anarchism. These two arguments are distinct in that they commit the philosophical anarchist to different claims, and as a result, different implications follow from those commitments. The a priori anarchist argument argues that the very nature of the state itself entails that it will always be illegitimate. Simply put, state legitimacy is a contradiction in terms, much like the squared-circle or the married-bachelorette. On the other hand, the a posteriori anarchist argument maintains that should some strict criteria for legitimacy exist, and a state does not meet those criteria, then that state is not legitimate. In this sense, illegitimacy of the state is not assumed a priori, but rather 
shown to be the case by appeal to the failure to satisfy necessary criteria for state legitimacy. Another important distinction to be made between the a priori argument and the a posteriori argument for state illegitimacy is that the a posteriori argument doesn't deny the logical or rational possibility of a legitimate state. Since certain values are being used as conditions for legitimacy, if those conditions were met, then there would be a legitimate state. What the a posteriori approach to illegitimacy argues is that actual states are illegitimate, not all possible states. The a priori approach to illegitimacy, however, is committed not just to the illegitimacy of actual states, but also to the illegitimacy of all possible states.

Wolff provides an example of an a priori argument for state illegitimacy. Wolff argues that the defining feature of the state is authority. In other words, the state must have authority in the affairs of its subjects in order to exist. For Wolff, the state and authority are intimately linked and inseparable. If they weren't, and the state did not in fact possess authority, then the state is nothing more than a de facto state; it would simply be claiming and acting in a manner that assumes authority, but does not actually possess any authority. In order for the state to be the sole rightful imposer of laws and duties, then it must have a monopoly of authority or else it cannot possibly be so. This leads Wolff to conclude that the "defining mark of the state is authority, the right to rule" (Wolff 1998, 18).

Additionally, Wolff argues that the capacity for autonomy means that at the end of the day, since I am autonomous, I am responsible. Wolff premises his argument that at the heart of moral philosophy is the notion that I am free and capable to act in ways 
that I choose, to be autonomous, and as a result I am responsible for my actions. Because of my capacity for autonomous decision-making and the capacity to act autonomously as a result, I am obligated to take responsibility for my actions. For this reason, I have a moral obligation to resist and oppose outside authority, since permitting such authority would be a contradiction of my obligation to be responsible. Since I am an autonomous person I must be responsible for my actions, and cannot do so if I am not authoritative in my decisions, therefore I must resist outside authority.

Wolff argues that the authority of that state is in direct conflict with my obligation to be responsible for my actions. Since the state must have authority over me in order to be more than simply a de facto state, then that means it must circumvent my own autonomous decision- making. In other words, the authority of my autonomy and responsibility must be compromised in order to allow the state to have true and meaningful authority and to be able to be the sole rightful imposer of laws and duties. However, I have an obligation to be responsible for my actions since I possess the capacity for autonomous decision-making, and as such, have an obligation to defend my authority as the sole imposer of duties for myself. My moral obligation to be my own authority comes in direct conflict with the state's claim that it be the sole authority over me in matters legislated by the state, and is thus not morally permissible. Thus, since the state, and the authority it requires, by nature contradict my moral obligations to be responsible for myself, the state cannot be morally legitimate.

Simmons's arguments for the illegitimacy of the state present an example of an $a$ posteriori argument for state illegitimacy. Simmons argues that a state is legitimate only 
if it has been voluntarily consented to by those it claims as its subjects. For Simmons, the only immediately legitimate claims of duties are those which he calls natural duties; these are duties which are the natural result of the state of nature such nonmaleficence and reciprocity. For this reason, any additional duties bestowed upon me have no natural force over me, and for this reason, I must consent to them in order for them to have any force. In other words, the only legitimate authority over my autonomy to decide and direct my course of action belong to natural duties, and other duties only have authority if they are those which I have expressed consent to abide by. Any other form of authority is not morally sound.

The state, for Simmons, is an artificial construct, and as such, has "no natural claims on our allegiance or compliance". Since the state is artificial, I have no natural duty to respect its authority; rather, it represents a body that I may engage in contract with if I so choose. Thus, the state can have authority only if I engage in voluntary contract with it. The only possible way a state can be said to possess a natural claim to my allegiance is if it is necessary for fulfilling my natural duties. Simmons argues, however, that this is a dubious claim. It seems entirely plausible to Simmons that a person can act morally and fulfil moral obligations without consenting to state authority, and therefore, there is no clear reason to accept the notion that the state is necessary to fulfil moral obligations. For example, I may well accept and abide by my duties to not hurt people or steal things, but rather to promote safety and contribute to collective well-being without accepting and consenting to state authority. For this reason, the state and its authority must be voluntarily consented to. 
Simmons considers his voluntarist approach to state legitimacy an a posteriori anarchist argument, since although it may be possible, or rationally conceivable, for a state to be legitimate according to his voluntarist ideals, no such state actually exists. It is a matter of fact that every state imposes duties and claims authority over its subjects without the universal consent of all who fall under it. However, since the state and its authority are artificial, and not the valid result of natural duties, then the state and its authority must be consented to for legitimacy. Since the state acts without the universal consent of those subject to it, the state is not legitimate.

\subsection{Evaluating Philosophical Anarchism}

For two reasons, I argue that the a posteriori argument for state illegitimacy is more consistent and coherent for understanding how a state can be illegitimate. The first is the intuitive force that ideals, values, and obligations can be used to construct rationally conceivable states which are legitimate. As Simmons argues, "[if] the anarchist values autonomy or free choice ... [or similarly], if the anarchist values equality or community, say, it is hard to believe that a strict egalitarian state, or the kind of state favoured by strict [values], could not be defended in those terms as an ideal of political legitimacy" (Simmons 2001, 110-111). Since Wolff's a priori approach is founded on the ideals of autonomy and responsibility, and if it were rationally conceivable that state can be organized around such ideals, then it would seem Wolff would have to submit to the rational conceivability of a legitimate state, no matter how hypothetical. Moreover, it 
would seem that Wolff does indeed argue as such, when he concedes that a unanimous direct democratic state would be legitimate, but that it is simply empirically impossible (Wolff 1998, 22-23). As such, it would seem that continuing to approach state illegitimacy by championing certain ideals from an a priori analysis would, at the very least, be rationally inconsistent.

Secondly, I also argue that an a posteriori approach to state illegitimacy falls more into line with the actual tradition of anarchism as a political ideology. Throughout the history and development of anarchist literature, anarchist thinkers have developed ideal forms of organization premised on certain values. ${ }^{11}$ Further, these thinkers would in turn use the existing state's failures to meet criteria for legitimacy as reasons for arguing that current states were illegitimate. Although many of these thinkers would be hesitant to use the word "state" for the systems of ideal organization they proposed as being legitimate, the organizations proposed were bodies of people that would make institutions to govern the political community. This seems, to me, entirely consistent with the understanding of state, political obligation, and legitimacy that I have developed thus far, and also with the a posteriori approach to state illegitimacy outlined above; it would not be consistent, however, with an a priori conception of state illegitimacy.

It is because of these reasons that I will continue my argument from an $a$ posteriori anarchist approach. This approach is consistent, in that it can accommodate

\footnotetext{
${ }^{11}$ See, for instance, Emma Goldman's Anarchism and Other Essays or Kropotkin's The Conquest of Bread, as possible examples.
} 
our theoretic intuitions about what could validly follow from commitments to certain ideals, unlike the a priori approach which would have us reject such intuitions. It is also coherent with a greater body of anarchist though, in that it follows the tradition and development of most of the anarchist literature and arguments, while the a priori approach seems to have little coherence with this tradition. Thus, I will continue with the premise that only a posteriori conceptions of state illegitimacy provide consistent and coherent means of evaluating whether the state is in fact illegitimate.

Now that I have established that only by employing a posteriori arguments can philosophical anarchism be internally consistent and coherent with the anarchist tradition, I can turn to evaluating just how strong those arguments can be. To do this, I will evaluate the strength of Simmons's voluntarist-anarchist arguments against what Simmons considers the major competitors to his understanding of state legitimacy. These views provide unique arguments for why the state and its authority is, in fact, legitimate. Therefore, any argument seeking to undermine the legitimacy of the state, its authority, or its use of coercion, must also undermine these views, or evolve to continue to be relevant. I argue that Simmons's arguments against many of these competitors fail, illustrating the shortcomings of his own voluntarist argument.

I find many of Simmons's arguments against popular accounts for state legitimacy given by Kantians compelling for simple reasons. The Kantian approach, simply put, is the argument that in order to live up to our moral obligations to each other, political obligation is necessary (Simmons 2001, 140). In other words, we must each accept and abide by state authority for us to fulfil our moral obligations and not 
infringe on each other's rights. This, as Simmons convincingly argues, is not at all evident. Simply because someone refuses to accept political obligation is not enough to conclude that moral obligations are not being met (Simmons 2001, 141). One can still conceivably pose no threat to the safety and well-being of others, and even actively contribute to the safety and well-being of others, without necessarily accepting political obligation. Thus, the Kantian defense of state legitimacy seems to, at best, be lacking in further argument to properly provide an argument for state legitimacy.

Simmons's arguments against Rawls and public justification, on the other hand, seem less convincing because they rest on a misrepresentation of Rawls. Simmons argues that Rawls's notion of public justification is far too relative to provide an actual account of state legitimacy. For Simmons, public justification is offered only to determine the structure of the state and only with regards to a specific population. This, Simmons argues, makes the notion of state legitimacy relative to only those that have already accepted the legitimacy of the state and only to particular populations. Simmons's arguments, however, seem to crucially miss the notion that public justification is offered to provide a reason for obedience to particular state models. For Rawls, obedience to the state is only owed when it can be shown, through public justification, that such obedience is necessary for the reciprocity needed to maintain civil society (Rawls 2005, 446-447). Further, the rejection of legitimizing the state in such a way as to make it legitimate to those that will be governed also seems unreasonable, and rejects the plurality of values and beliefs that can be found among citizens. 
Most damning for Simmons's voluntarism, I argue, are the arguments he uses against the Weberian approach to state legitimacy championed by many. What this approach argues is that the state is legitimate not due to any independent existence or properties, but rather by the way people generally think about their state and their actions and attitudes towards it (Simmons 2001, 132). For the Weberian approach, the state will be legitimate simply if the people generally consider the state to be legitimate, and act and behave towards it as such (Simmons 2001, 132). It is important to note that much of the normativity that I have been using and developing throughout this essay is of zero relevance to the Weberian. For them, a state is legitimate not by any normative force, but rather by satisfying and manifesting general descriptive features.

In defending his voluntarist argument for the illegitimacy of the state, Simmons argues that the Weberian's conception of state legitimacy is flawed for two significant reasons. Firstly, rather than identifying some feature or characteristic of the state itself, it focuses on some feature or characteristic of its subjects (Simmons 2001, 133). However, an ideal account of state legitimacy would focus on the state itself, identifying a feature of the state which could serve as the means of evaluating its legitimacy (Simmons 2001, 133). Secondly, as Simmons notes, "[s]urely by now the history of human oppression has taught us how often people come to feel obligated toward and believe in the rights of those who simply wield over them irresistible power, with no more moral authority over them than such power wields" (Simmons 2001, 134). What Simmons draws attention to here is the important fact that people may be misled, misinformed, deceived, habituated, or compelled by propaganda into accepting the 
claim that the state is legitimate. Indeed, there are many very frightening states that can be easily concluded as legitimate if one accepted the descriptive criteria outlined by the Weberian. This second reason, on its own, seems sufficient enough to reject the Weberian's conception of state legitimacy.

The arguments Simmons uses to refute the Weberian conception of legitimacy, however, reveal what I take to be some significant shortcomings of his own voluntarist conception. Specifically, the objections Simmons employs against the political realist seems just as applicable to his own voluntarist arguments. With regards to the first of his objections, focusing on whether or not the subject has given voluntary consent to be governed seems to shift the focus for legitimacy from the state to the subjects just as much as the political realist does. If all that is needed is the citizens' consent, then there is no feature of the state itself that is being identified as the means of evaluating the state's legitimacy. Secondly, Simmons's objection that people, for various reasons, can be influenced to believe things about the state that are untrue, and to have certain feelings about the state fostered in them, also seems just as applicable to his criterion of voluntarism. It seems entirely plausible that people can be deceived into giving their consent.

Thus, Simmons's arguments fail to actually defend philosophical anarchism. His arguments against Rawls and his notion of public justification ignore a crucial feature of Rawls's argument: that public justification is given to lay the framework for political obligation. Therefore, Simmons's arguments, at the very least, are indefensible against Rawlsian approaches to philosophical anarchism. Additionally, Simmons's arguments 
against Weberian approaches to state legitimacy are equally applicable to his own voluntarist approach to state legitimacy. Thus, if his objections against Weberians gives reasons for rejecting their approach to state legitimacy, then his objections are equally applicable to his own voluntarism. These shortcomings of Simmons's arguments present objections worthy of consideration when determining the plausibility of philosophical anarchism.

\subsection{The Move to Participationism}

These problems can be easily overcome with a shift from voluntarism to participationism that still embodies the motivations for voluntarism, but with none of its shortcomings. Participationism as a criterion for evaluating state legitimacy would understand a state to be legitimate if the state's exercise of its authority is the direct result of the participation of its subjects, so that the state's authority in fact represents the authority of its subjects. Through the active participation of citizens in the decisionmaking mechanisms of the state, the decisions reached will be the decisions of the citizens themselves. This places state authority in the hands of the citizens, effectively making state authority the authority of the citizens. As a result, political obligation is self-assumed by citizens of participationist society, and reflects the citizens own exercise of their own autonomy. Thus, autonomy is preserved by the constant and active participation in state decision-making mechanisms. 
By stressing the value of citizen participation as means of evaluating the legitimacy of the state, we can properly shift our focus onto the state itself when determining the state's legitimacy. This can be accomplished by analyzing how well the state fosters and provides forum(s) for participation, and how legislation is made. Further, active participation can serve as the very means to ensure that citizens are not merely manipulated into accepting state authority or being deceived to give their consent. By participating in the mechanisms of the state, the individual plays a role in determining just what they will decide to and give consent to. Additionally, by actively participating with others in determining what projects the state will or will not undertake, the individual has the opportunity to listen and respond intelligently to others, if only to have their own views taken seriously. This active consideration of others' propositions and evaluation of our own counteracts the possibility that political obedience is given frivolously or obtained fraudulently. Additionally, by consistently working with fellow citizens to govern themselves, public justification is constantly under review and being constructed by the citizenry themselves, providing what may be the clearest and most definitive expression of public justification possible. Thus, participationism overcomes the shortcomings of Simmons's voluntarism.

It is beyond the scope of this article to give a systematic account of what a state that can be classified as participationist looks like. Despite this, there are some inspirational examples of participationist organization which can help us to grasp the possible form of a legitimate state. First, there is participatory budgeting in Kerala, India, where the allocation of a large portion of developmental aid funds is determined 
by participatory mechanisms (Isaac and Heller 2003, 78). Secondly, there is participatory public school and policing mechanisms in Chicago, where community members can actively participate with their local school and police officials to determine how those services are run in their community (Fung 2003, 111-112). Lastly, there is the worker owned and run Zanon factory in Argentina, where employees work together in every aspect of management (Trigona 2008, 155). These three examples provide some worthwhile considerations for understanding the type of decision-making mechanisms that the state can utilize to make its authority better reflect the autonomy of citizens and thus increase its legitimacy.

Firstly, each of these examples make use of the general assembly to allow people to participate in the governance of their institutions. In Kerala, assemblies are held in local urban municipalities and rural districts, blocks, and villages where citizens get together to discuss issues, develop priorities, and begin to construct development strategies and form task forces to work out the strategies (Isaac and Heller 2003, 84, 9091). Similarly, in Chicago, each public school and police beat hold regular meetings, where citizens can voice concerns and proposals, and develop with local officials a means to achieve their goals (Fung 2003, 113). Likewise, at the Zanon factory in Argentina, worker assemblies are held where issues such as wages, safety measures, workloads, hiring, and production planning are discussed and voted upon (Trigona 2008, 161). Assemblies such as these provide a forum for all to participate in a participationist government structure, which listens and considers to all those who wish to participate in their governance. The general assembly model for determining which course of 
action should be taken in resolving social, political, or economic issues provides, at the least, a model for developing participationist organizational structures.

Secondly, these examples provide a fruitful, practical means of understanding how coordination can be achieved through a participationist organization structure. In many cases, different committees made up of participants are formed and given the task of discussing, analyzing, and developing strategies for particular issues. Kerala's local assemblies form development seminars and task forces to research and develop strategies to realize the mandates of the assembly, Chicago's public school assemblies form local school councils to work out budgets as well as hiring/firing policies, and Zanon forms committees as well as nominate regularly rotating shop coordinators to facilitate work (Isaac and Heller 2008, 93; Fung 2003, 113; Trigona 2008, 160). These committees have regular meetings, where everyone involved in the committee, and even those affected by the committee's subject, participate in choosing a course of action that they wish to pursue. From these examples, then, we can also take away how more specific and particular issues, that would require special focus, can be worked out by a participationist state.

Lastly, these examples all make use of mechanisms that provide the means to develop the skills necessary for citizens to actually and effectively develop strategies for realizing their goals. Each of these examples have made use of either important training or consultation from experts to aid participants in both holding productive assemblies and developing strategies and plans that are actually feasible. Kerala's task forces regularly seeks consultation from the state's Voluntary Technical Corps in developing 
particular strategies and projects (Isaac and Heller 2008, 95). Chicago provides administrators to local school councils to facilitate ineffective and failings councils as well as training in developing and working budgets, and legal support to address particular concerns raised at police beat meetings (Fung 2003, 122, 133-134). Finally, Zanon workers can get training and advice from accountants and lawyers to effectively manage their workplace (Trigona 2008, 160). Each of these examples provides an understanding of how the participationist state can develop the ability of citizens to be active participants.

These three features of the participatory models at work in Kerala's local budgets, Chicago's public schools and police beats, and Argentina's Zanon factory, provide useful glimpses as to how a participatory society might function. Firstly, general assemblies would be regularly held, where citizens could voice concerns and issues, and begin to prioritize issues as well as begin to identify what measures need to be taken. From there, citizens can then form specific committees to work on and devote time to specific issues, and develop concrete strategies to achieve the goals of the general assembly. Finally, citizens are given the opportunity and means to learn how to recognize and evaluate issues as well as to develop effective strategies to realize their goals.

\subsection{Evaluating Participationism}


It may be objected that participationism, when practically analyzed, simply reduces to a voluntarist conception of state legitimacy. In other words, in order for participationism to be truly legitimate, along the lines sketched in the above examples, then it must be voluntarily consented to. The voluntarist can argue that participatory states are still artificial states, and as such can claim no natural duty on people to participate. Since participationist states cannot claim natural duties of people, the participationist state can only be legitimate towards only those who voluntarily consented to it. Thus, the legitimacy of participationist states depends on the voluntary consent of citizens. Thus, participationist conceptions of state legitimacy simply reduce to voluntarist conceptions of state legitimacy.

I would not argue that participationism does not, in fact, require voluntary participation. Moreover, I argue that in so far as meaningful participation is the key to state legitimacy, then participation must be voluntary. If I am forced into participating in something I don't wish to participate in, then my participation will not be the result of my autonomous decision-making process, but rather the decision-making process that I am being forced into. In so far as the participation that results is not the result of my own autonomy, then it is clearly not my participation. Further, the value of my participation only increases when I am given the choice to voluntarily participate, since I will be free to truly express what is important to me rather than being compelled to accept and conform. For these reasons, I do not intend to deny that voluntarism, is indeed, an important feature of participationism. 
I do argue, however, that participationism entails more than just voluntary consent. What makes participationism distinct from voluntarism is that one must not only voluntary consent, but actively participate in deciding upon laws, and have those laws represent their own authority, in order for those laws and their authority to be legitimate. In this sense, despite voluntarism being necessary for participation, it alone is not sufficient for state legitimacy. Participationism preserves the ideal of autonomy that motivates voluntarism but argues that consent is not enough and that active participationism is also necessary so as to overcome voluntarism's short-comings made apparent by the objections against Weberians. As such, I argue that a philosophical anarchist argument can embrace participationism without contradicting a commitment to autonomy. Further, by embracing participationism, philosophical anarchists can defend themselves and respond to powerful objections. For these reasons, I argue that a philosophical anarchism motivated by participationism presents a stronger candidate for understanding state illegitimacy.

I argue that if one were to accept participationism as the criterion for determining state legitimacy/illegitimacy, from an a posteriori account of state illegitimacy, then philosophical anarchism follows. This argument, I think, is not very hard to make. There does not exist a single state which is the sole imposer of laws within a given territory, that derives its legitimacy from the participation of all those who are subjects to its supremacy and authority. States are illegitimate if they do not satisfy the participationist criterion; that is, if states impose their supremacy and authority over those who have not participated in the imposition of duties and laws, and 
demand submission, then they are illegitimate. Thus, there does not exist a completely legitimate state, since no state exists that derives all of its authority in all legislated matters from participatory mechanisms. Although it is difficult to know with any real clarity what such a state may look like, and what is necessary for citizen participation, the examples discussed above provide some insight and attempt to understand what a participationist state would be. Despite this, however, common sense seems to indicate that there has yet to be a state to fully attempt comprehensive and robust participatory decision-making mechanisms in all of its affairs.

The most notable objection to the idea that a participationist approach to state legitimacy is philosophically anarchist is offered by Carol Pateman. Pateman also adopts a participatory approach to legitimate state authority, but argues against philosophical anarchist approaches to state legitimacy. However, Pateman's objections against philosophical anarchism are made largely in response to the philosophical anarchism of Wolff. Pateman argues that Wolff defines "authority" and "autonomy" in such a way that these two concepts will necessarily conflict; in other words, Wolff has rigged his argument in favour of state illegitimacy (Pateman 1985, 137). For Pateman, Wolff's claim that all authority is illegitimate ignores a whole other aspect to authority, that is, that authority can enable and reflect autonomy. Pateman argues that under a participationist society, obligation and authority are self-assumed through the active participation in governance. Thus, Pateman argues that authority may not necessarily be an imposition on individuals, but may also be a possible means of empowering the autonomy of citizens (Pateman 1985, 137). As such, Pateman is not convinced by 
Wolff's arguments that authority and autonomy are necessarily in conflict and rejects his philosophical anarchist conclusion.

The problem with Pateman's rejection of philosophical anarchism is that her arguments are levelled only towards the a priori philosophical anarchism of Wolff, and cannot be applied to a posteriori approaches to philosophical anarchism. Her arguments are against the conceptual impossibility of legitimate state authority, not the notion that states fail to live up to a condition of legitimacy. As such, her arguments against $a$ priori anarchists such as Wolff provide no reason to reject $a$ posteriori approaches to philosophical anarchism. The question of whether or not there exist states which satisfy the participationist criterion for legitimacy still remains to be answered, and there really is no reason to assume that such a participationist state actually exists. Pateman seems to concede as much in defending her participationist approach to legitimate state authority by arguing that traditional liberal democratic states fail to realize moral legitimacy. In this regard, we can understand Pateman as concluding that many states are in fact illegitimate for not realizing the condition of moral legitimacy of authority. For these reasons, I do not see participationism in conflict with philosophical anarchism, as it is only antithetical to a priori approaches to philosophical anarchism, but not to a posteriori anarchism. 


\subsection{Conclusion}

The preceding arguments, I believe, are more than sufficient to accept a philosophical anarchist argument for the illegitimacy of states as sound. By establishing a clear understanding of the concepts, I was able to evaluate the strength of a posteriori accounts of state illegitimacy over a priori accounts. Once I established that this method was an acceptable means of evaluating state legitimacy, I analyzed Simmons' a posteriori arguments for the illegitimacy of the state. What I found is that his arguments against the Weberian approach to legitimacy also argue against his own voluntarist approach. I then used these shortcomings to develop a participationist approach to evaluating state legitimacy, which I showed to preserve the ideals of voluntarism yet retain none of its shortcomings. Although much work and research is needed to understand if a state has achieved a robustly participationist democracy, common knowledge would seem to indicate that much is lacking from contemporary states in this regard. Should further research vindicate this intuitive observation of states' lack of robust participation, then philosophical anarchism will follow. Since participationism can develop an approach to determining state legitimacy, and the foregoing arguments provide valid reasons to accept participationism, and should states' be shown to fail to achieve robust participationism, then we have all the elements of a sound argument for philosophical anarchism. 


\section{Bibliography}

Chicago Public Schools. "Local School Council". CPS.edu.

http://www.cps.edu/pages/Localschoolcouncils.aspx (accessed June 17, 2014).

Dagger, Richard, "Political Obligation". The Stanford Encyclopedia of Philosophy

(Summer 2010 Edition), Ed. Edward N. Zalta. URL =

<http://plato.stanford.edu/archives/sum2010/entries/political-obligation/>.

Franke, Richard W. "Local Planning: The Kerala Experiment". Real Utopia: Participatory Society for the $21^{\text {st }}$ Century. Ed. Chris Spannos. Oakland, CA: AK Press, 2008. pp. 130-135

Fung, Archon. "Deliberative Democracy, Chicago Style: Grass-roots Governance in Policing and Public Education". Deepening Democracy: Institutional Innovations in Empowered Participatory Governance. Ed. Archon Fung and Erik Olin Wright. New York, NY: Verso, 2003. pp. 111-143

Goldman, Emma. Anarchism and Other Essays. Indore, India: Modern Printery Ltd, 1914 Isaac, T.M. Thomas and Patrick Heller. “Democracy and Development: Decentralized Planning in Kerala". Deepening Democracy: Institutional Innovations in Empowered Participatory Governance. Ed. Archon Fung and Erik Olin Wright. New York, NY: Verso, 2003. pp. 77-110

Kropotkin, Peter. The Conquest of Bread. Oakland, CA: AK Press, 2007

Manz, Charles C., Karen P. Manz, Stephen B. Adams, \& Frank Shipper. "Sustainable performance with Values-Based shared leadership: A case study of a virtuous 
organization". Canadian Journal of Administrative Sciences / Revue

Canadienne des Sciences de l'Administration 28, (3) 2011: 284-296.

Marquetti, Adalmir, Carlos E. Schonerwald da Silva, and Al Campbell. "Participatory

Economic Democracy In Action: Participatory Budgeting In Porto Alegre, 1989-

2004". Review of Radical Political Economics 44.1 (2012): 62-81.

Pateman, Carole. Participation and Democratic Theory. Cambridge, UK: Cambridge University Press, 1970

Pateman, Carole. The Problem of Political Obligation: A Critique of Liberal Theory. Cambridge, UK: Polity Press, 1985

Pettit, Philip. "Participation, Deliberation, and We-Thinking". Illusion of Consent:

Engaging with Carole Pateman. Ed. Daniel I. O’Neill, Mary Lyndon Shanley, \& Iris Marion Young. University Park, PA: Pennsylvania State University Press, 2008.

pp. $185-204$

Rawls, John. Political Liberalism: Expanded Edition. New York, NY: Columbia University Press, 2005

Simmons, A. John. Moral Principles and Political Obligations. Princeton, NJ: Princeton University Press, 1979

Simmons, A. John. "Justification and Legitimacy". Justification and Legitimacy: Essays on Rights and Obligations. Ed. A. John Simmons. Cambridge, UK: Cambridge University Press, 2001. pp. 122-157 
Simmons, A. John. "Philosophical Anarchism". Justification and Legitimacy: Essays on Rights and Obligations. Ed. A. John Simmons. Cambridge, UK: Cambridge University Press, 2001. pp. 102-121

Trigona, Marie. "FASINPAT (Factory Without A Boss): An Argentine Experience in SelfManagement". Real Utopia: Participatory Society for the 21st Century. Ed. Chris Spannos. Oakland, CA: AK Press, 2008. pp. 155-168

Wellman, Christopher Heath \& A. John Simmons. Is There a Duty to Obey the Law? Cambridge, UK: Cambridge University Press, 2005

Wolff, Robert Paul. In Defense of Anarchism. California, USA: University of California Press, 1998 